\title{
Die glückliche Vorbedeutung and Aristheus: \\ Unknown Libretti of German-Language Operas \\ Performed in the Kärntnertortheater in Vienna
}

\section{in $\mathbf{1 7 4 1}$}

Jana Perutková / perutkov@phil.muni.cz

Department of Musicology, Faculty of Arts, Masaryk University, Brno, CZ

\begin{abstract}
This article focuses on newly identified librettos of operas set to original German texts and produced at the Kärntnertortheater in the 1740s. The opera Die glückliche Vorbedeutung premiered in the spring of 1741 as part of the grandious celebrations of the birth of Archduke Joseph, the first son of Maria Theresa. The next German-language opera, Aristheus, was produced during the same year both in Vienna and Graz. Finally, the third opera, Hypsipile, was produced sometime before 1747. All three works should be understood in the social and political context of the Wars of the Austrian Succession.
\end{abstract}

\section{Keywords}

Vienna, opera, Kärntnertortheater, German language, Maria Theresa, Joseph II, Pragmatic Sanction, War of the Austrian Succession 


\section{Prologue: Performances of Italian musical-dramatic works in German translations in the Habsburg monarchy before 1740}

The reign of Emperor Charles VI (1711-1740) was the heyday of the Italian dramma per musica in the Habsburg monarchy. Its general popularity was undoubtedly related to the prevailing taste at the court, especially the emperor himself. Unlike in other German cities (Hamburg, etc.), serious operas at the imperial court were staged exclusively in Italian, the genre's native language; this also applies to operas staged at aristocratic and urban opera theatres in the Habsburg monarchy. The only librettos printed in German were those with an informative translation of the Italian texts, either as separate books (at the imperial court and at various aristocratic residences) or together with Italian texts (always as mirror pages in Italian and German), as was the case in various opera companies - in Vienna, Graz, Prague, Brno, Wroclaw, Ljubljana, etc.

The only known exception in the aristocratic environment has been, until now, Count Johann Adam von Questenberg (1678-1752), who staged at least two drammi per musica in German at his estate in Jaroměřice (Jarmeritz) in Moravia; the German texts, however, were based on music originally composed to Italian libretti. The first of the above was the opera L'amor non ha legge, composed by the imperial court composer and Vicekapellmeister Antonio Caldara in 1728 to the libretto by Giovanni Bonlini at Questenberg's request. ${ }^{1}$ A remark in the German version of the libretto, which states that the translation was to make it possible to sing the aria in Italian and German, is a proof that the opera could have been performed in both languages. ${ }^{2}$ The second example is the opera L'origine di Jaromeriz in Moravia from $1730 .{ }^{3}$ The author of the Italian libretto, which was also set to music by Questenberg's home composer František Antonín Míča (Franz Anton Mitscha), was once again Bonlini. Regarding the German translation, Questenberg's Hofmeister Georg Hoffmann Adam reported that the translator - the renowned playwright, actor and principal Heinrich Rademin - was trying to write the German text so that the opera could be sung in German, too, though this was not an easy feat. ${ }^{4}$ In

1 Venetian patrician Giovanni Domenico Bonlini wrote five texts for Count von Questenberg in 1728-1732. For details cf. PERUTKOVÁ, Jana. Der glorreiche Nahmen Adami. Johann Adam Graf von Questenberg (1678-1752) als Förderer der italienischen Oper in Mähren (= Specula Spectacula 4). Wien: Hollitzer Verlag, 2015 (hereinafter PERUTKOVÁ 2015), passim.

2 "Man hat in der Übersetzung von dem Wällischen in das Teutsche, so viel es die Möglichkeit zugelassen sich dahin bearbeitet, dass die Arien auch teutsch wie in wällisch mögen gesungen werden." A German libretto called Die Liebe hat kein Gesatz in A-Baden, A 453. Translation of the libretto into German was created by Martin Anton Prunauer, a Vienna tax officer in a relatively prominent position.

3 Based on operatic works celebrating Emperor Charles VI, Count Questenberg appeared as the main heroic character in both operas. German adaptations were supposed to bring the operas closer to Questenberg's friends from the lower aristocracy. On this issue cf. PERUTKOVÁ, Jana. Von der mährischen Aristokratie in der ersten Hälfte des 18. Jahrhunderts veranstaltete musikdramatische Aufführungen als Spiegel musikalischer Feste am Wiener Kaiserhof. In Die Repräsentation der Habsburg-Lothringischen Dynastie in Musik, visuellen Medien und Architektur / Representing the Habsburg-Lorraine Dynasty in Music, Visual Media and Architecture.1618-1918. Ed. Werner Telesko. Wien - Köln - Weimar: Böhlau Verlag, 2017, pp. 284-300. Available online [11. 6. 2018] https://www.vr-elibrary.de/doi/pdf/10.7767/9783205207153.284. The work L'origine di Jaromeriz in Moravia was also performed in Czech.

4 Hoffmann's letter to the Count from May 7, 1730: "Rademin meldet, es werde sehr gezwungen, absonderlich in 
addition, regarding dramma per musica, Questenberg experimented not only with German, but also with French. ${ }^{5}$

However, it was not simple to set German lyrics to music originally composed for Italian librettos, as evidenced in the preface of the oratorio Die obsiegende Liebe performed by the Jesuits at the Holy Sepulcher in Prague in 1717. ${ }^{6}$ The introductory page, "An den Hoch-günstigen, Andacht-Befliessenen Leser", states:

\begin{abstract}
"Weil man sich entschlossen, nicht allein die Kunst-mässige Wälsche Sing-Art in gegenwärtigem Oratorio unverändert zu behalten; sondern auch den Nachdruck der Wälschen Red-Art in Teutscher Sprache auffs möglichste nachzuähnen: So hat doch dieses letztere ohne Zwang der Hoch-Teutschen Mund-Art nicht allerseits können bewerckstelliget werden: Sintenmahl ein Vernünffiger leichter achten wird, wie schwer es falle, ein Poësie auß einer Sprache in die andere, mit gleichen Syllaben und Verstande, mit Obachtung zugleich der Sing-Music zu überbringen. So dann wird der geneygte Leser desto gutwilliger entschuldigen, wann da und dort etwelche Red-Arten wider die Reinigkeit der Teutschen Sprache, wider die Poësie und Reim-Kunst vorkommen werden. Unser Vorhaben ware allen in der Andacht zu dienen. $\mathrm{Zu}$ dem Ende wir diese Music den Ohren, diese wenige Blättlein den Augen deß Andachtbefliessenen Zuhörer- und Lesers dienstwilligst wollen gewidmet haben."
\end{abstract}

The introduction emphasizes the difficulties in translating texts that were supposed to be set to the original Italian oratorio. ${ }^{7}$

Some arias in German were also introduced - though this must have happened rarely - in Italian drammi per musica presented by the Italian opera company in Wroclaw (Breslau). One of the few reports of this was published by the Schlesischer Nouvellen-Courier magazine, which announced it for the opera Dafni by Baron Emmanuel d'Astorga

Arien, herauskommen, doch werde er sich mit übersetzung alles fleises gebrauchen, damit es auch teutsch könne gesungen werden." PERUTKOVÁ 2015, p. 411, on Rademin see p. 250-251.

5 A French passage was inserted into the Italian libretto of the opera L'elezione d'Antioco in re della Siria. The libretto was commissioned by Count Questenberg from Bonlini in 1732. After the second act, the "Siegue l'Introduzzione, e Balli alla Francese" follows in the libretto instead of the ballet and the section (Sixieme Entrée, III/2) is taken from the Opéra-Ballet Fêtes de l'Amour et de Bacchus from 1672. The libretto to this work was created by Philippe Quinault, music composed by Jean-Baptiste Lully. It is likely that this part was adopted in L'elezione d'Antioco in re della Siria, including Lully's music. The Italian dramma per musica therefore surprisingly contains a French-type divertissement with short choral sections in French. Cf. PERUTKOVÁ 2015, pp. 514-519.

6 The title sheet of the oratorio reads as follows: Amoris in iudicio victoria oder Die obsiegende Liebe, in dem, wider das Menschliche Geschlecht, wegen dess grausamen Christi-Mords, von der göttlichen Gerechtigkeit angestellten Hals-Gerichte, vormahls in Neapol, anjetzo aber in der Kirchen S. Nicolai Soc: Jesu, der königlichen kleinern Statt Prag, am H. Charfreytag Nachmittag um 12. Uhr. zu andächtiger Betrachtung in hoch-teütscher Sprache melodisch vorgestellet, von einer Edlen Music-Befliessenen Compagnie. Cum Licentia Superiorum. Alt-Stadt Prag: gedruckt bey Wolffgang Wickhart, Ertz-Bischoffl. Buchdr., 1717 (CZ-Pu, 52 C 20, adl. 29).

7 However, notes such as the one in this libretto are rare. It follows that similar language "experiments" were not too frequent. It is also possible to agree with the opinion of Václav Kapsa that this oratorio might have had something to do with the Prague concert institute functioning under the name of Musicalische Akademie, established in 1717, and the commentary on the translation was probably intended for the aristocratic society rather than the ordinary believers in the audience. Cf. KAPSA, Václav. Die Musik in der St. Nikolauskirche auf der Prager Kleinseite in der ersten Hälfte des 18. Jahrhunderts. Musicologica Brunensia 49, 2014, iss. 1, pp. 189-209, DOI: 10.5817/MB2014-1-12; the hypothesis on p. 199. 
in 1726. Jana Spáčilová also recently identified three inserted German arias in Endimione, which was staged in Wroclaw in 1727; the author of the inserted arias was Daniel Gottlob Treu, a native of Stuttgart. ${ }^{9}$ It is therefore possible that these arias were composed to original German texts.

\section{Serious operas with original German librettos performed at Vienna's Kärntnertortheater in 1741}

The fact that several operas of dramma per musica type were staged in German language in Vienna in 1741 has not been known until the early 21 $1^{\text {st }}$ century. It was not until 2006 that Lawrence Bennet found the score of one of these operas, Hypermnestra. Based on the discovery of newly identified librettos, however, it is now clear that in 1741, at least two other German-language operas were composed for the Kärntnertortheater: Die glückliche Vorbedeutung and Aristheus. The staging of Hypsipile in the same year cannot be ruled out, either.

Immediately after the death of Emperor Charles VI, there was a strong tendency to stage serious operas with original German librettos. It took place at the Kärntnertortheater, which was one of the most important opera houses in the transalpine region. A lot of attention has recently been paid to staging of operas at the "kaiserlich-königlichen privilegierten Theater nächst dem Kärntnerthore" - in printed librettos and other archive sources often referred to as Teatro privilegiato. ${ }^{10}$

The theater was established in 1709, and staging German-language comedies played a major role since the beginning (linked to names like Joseph Anton Stranitzky, later Gottfried Prehauser, etc.). However, no operas were staged in the initial phase; the privilege to perform operas was granted by Emperor Joseph I to the Italian singer Francesco Ballerini. Although he owned the privilege up to his death (1734), Ballerini did not perform any operas there, most likely because of lack of financial resources. ${ }^{11}$ In 1728

8 "Die Composition der Musiqve ist von dem berühmten Cavallier Baron d'Astorga, ein Autor, von deme allhier in denen vorgewesenen Repraesentationen noch nichts gehöret worden: man flattiret sich gäntzlich, daß dieses Stück Approbation finden dürfte, zumahlen solches auch mit was lächerlichen und auf Wällisch, mit der parte buffa untermischet ist, deme noch beytritt, daß auch etliche Arien werden teutsch gesungen werden, damit Jedermann etwas davon verstehen könne." Quoted by: SPÁČILOVÁ, Jana. Počátky opery ve Slezsku - současný stav pramenů [The origins of the opera in Silesia - the current state of sources]. Musicologica Brunensia 51, 2016, iss. 2, pp. 157-170. DOI: 10.5817/MB2016-2-12.

9 Sheet music was identified by Spáčilová in Berlin (D-B), cf. SPÁČILOVÁ, Jana. Ibid. Treu's musical studies, possibly with Vivaldi, were paid for by the Duke Ludwig von Württemberg in Italy. In 1720s, he was active in the Wroclaw Opera Society, he presumably stayed in Vienna from 1727 to 1729, where he was active at the court of Count Questenberg, accoridng to his curriculum vitae. He then returned to Silesia. Cf. PERUTKOVÁ 2015, p. 238. His life and work deserve more detailed research.

10 Intensive research is being carried out within the framework of a project by Andrea Sommer-Matthis on OEAW Das Wiener Kärntnertortheater in der Zeit von 1728-1748: Vom städtisch-bürgerlichen Schauspielhaus zum höfischen Opernbetrieb.

11 Cf. SOMMER-MATHIS, Andrea. Die Anfänge des Wiener Kärntnertortheaters zwischen deutschsprachiger Stegreifkomödie und italienischer Oper. Divadelni revue 26, 2015, iss. 2, pp. 139-152 (heirenafter SOMMER-MATHIS 2015). 
the court singer and one of the most famous tenors of that time Francesco Borosini and the court dancer Joseph Carl Selliers became tenants of Kärntnertortheater. ${ }^{12}$ They were a pair of artists who can, to a large extent, be credited with introducing dramma per musica genre in Vienna outside the imperial court. Both artists, however, have received the often-quoted instruction from Emperor Charles VI that they can only stage "Comödien mit einigen untermischt gesungenen Intermedien" in this theater. ${ }^{13}$ Nevertheless, there was an enormous effort on the part of both Kärntnertortheater tenants to stage serious operas, especially in Italian, although they were often shortened or in the form of pasticcios. The number of compositions listed in 1728-1740 was indeed enormous, as evidenced by the preserved librettos. The number of premieres in the season was comparable and sometimes even higher than in some famous Venetian theaters. ${ }^{14}$ Those were often pasticcios based on works premiered primarily in Italy. Only a few composers are known to have composed directly for the Kärntnertortheater: Francesco Rinaldi, ${ }^{15}$ Franz Joseph Carl Pircker, who worked at the Kärntnertortheater as Musikdirektor, ${ }^{16}$ Johann Ignaz Beyer, ${ }^{17}$ Anton Phuniak, ${ }^{18}$ Antonio Bioni, ${ }^{19}$ Ignazio Maria Conti and Ignaz

\section{Ibid.}

13 Cf. for example HADAMOWSKY, Franz. Wien - Theatergeschichte. Von den Anfängen bis zum Ende des Ersten Weltkrieges [= Geschichte der Stadt Wien III].Wien 1994, p. 195; also SOMMER-MATHIS 2015.

14 I would like to thank Andrea Sommer-Mathis and Reinhard Strohm for their help and advice regarding this issue.

15 Rinaldi's origins, life and works (apart from three surviving operas compiled for Kärntnertortheater) have not been identified with certainty, either. Cf. PERUTKOVÁ 2015, pp. 198-199; Vienna Kärntnertortheater Singers in the Letters by Georg Adam Hoffmann to Count Johann Adam von Questenberg. Italian Opera Singers in Moravian Sources c. 1720-1740 (Part II). In Musicians' Mobilities and Music Migrations in Early Modern Europe. Biographical Patterns and Cultural Exchanges. Eds. Gesa zur Nieden and Berthold Over. Bielefeld: Transcript Verlag, 2016, pp. 275-292 (heirenafter PERUTKOVÁ 2016). Available online [11. 6. 2018] https:// www.transcript-verlag.de/media/pdf/24/94/a7/oa97838394350455b19e250cbe52.pdf.

16 Cf. SOMMER-MATHIS 2015, PERUTKOVÁ 2015, p. 185. A project led by Daniel Brandenburg Die 'Operisti' als kulturelles Netzwerk: Einblicke and Kontexte der Pirker-Korrespondenz [Italian Operisti as cultural network: insights and contexts of the Pirker correspondence].

17 Claudia Michels mentions him in relation witzh the Kärntnertortheater: MICHELS, Claudia. Opernrepertoire in Wien um 1740: Annäherungen an eine Schnittstelle. In Im Dienste einer Staatsidee: Künste und Künstler am Wiener Hof um 1740 [= Wiener musikwissenschaftliche Beiträge; Bd. 24]. Ed. Elisabeth Th. Fritz. Wien: Böhlau Verlag, 2013, pp. 125-158. Beyer's request for a post with the Bishop of Olomouc was first reported in SEHNAL, Jiř́i. Das Musikinventar des Olmützer Bischofs Leopold Egk aus dem Jahre 1760 als Quelle vorklassischer Instrumentalmusik. Archiv für Musikwissenschaft 29, 1972, iss. 4, pp. 285-317. Regarding his musical paraphernalia stored in Moravia see PAVLICA, Lukáš. Completorium a Cantata Johanna Ignaze Beyera - edice a analyza [Completorium and Cantata by Johann Ignaz Beyer - Edition and Analysis]. Diploma thesis, supervisor: Jana Perutková, Brno: FF MU, 2018.

18 Cf. SOMMER-MATHIS 2015, PERUTKOVÁ, Jana. Giulio Cesare in Egitto am Wiener Kärntnertortheater im Jahre 1731. Ein Beitrag zur Rezeption der Werke von G. F. Händel in der Habsburgermonarchie in der 1. Hälfte des 18. Jahrhunderts. Hudebni věda 49, 2012, iss. 1-2, pp. 95-122. Available online [11. 6. 2018] https:// kramerius.lib.cas.cz/search/nimg/IMG_FULL/uuid:eb56bc08-d1d8-46f7-be9f-3e23991b84d8\#page=1.

19 Cf. especially BRISTIGER, Michał - STROHM, Reinhard. "Libertà, marito e trono fur miei beni..." Die wiederentdeckte Andromaca von Antonio Bioni (Breslau 1730). In Opera Subjects and European Relationships [= Italian Opera in Central Europe, 1618-1780, Bd.3]. Eds. Norbert Dubowy, Corinna Herr and Alina ŻórawskaWitkowska. Berlin: BWV, 2007, pp. 73-109. PEGAH, Rashid-Sascha. Antonio Bioni und seine "Cantate Musicali" für Markgräfin Friderique Louise von Brandenburg-Ansbach. Jahrbuch für fränkische Landesforschung 72, 2012, 
Jacob Holzbauer. ${ }^{20}$ One opera for the Kärntnertortheater was also composed by Giovanni Porta. ${ }^{21}$

Ignaz Holzbauer is the author of the only known German-language opera - Hypermnestra, which was staged in the Kärntnertortheater in 1741 and set to the libretto by Johann Leopold van Ghelen. The score to this opera was identified in the collection of Duke Anton Ulrich von Sachen-Meiningen by Lawrence Bennett, who is also the author of the edition of this work published in 2014. ${ }^{22}$ Reinhard Strohm also published a crucial study about the opera in $2014 .^{23}$ Strohm demonstrates that Ghelen created his libretto for Hypermnestra on an opera pasticcio staged in 1731 in the Kärntnertortheater, which was in turn based on the Italian libretto to Ipermestra by Antonio Salvi.

\section{Die glückliche Vorbedeutung: its authors and the circumstances of the staging}

The opera Die glückliche Vorbedeutung was premiered on March 13 and repeated on April 23 and 24, 1741, as part of the opulent birthday celebrations of the first-born son of Empress Maria Theresa, the Archduke Joseph (the future Emperor Joseph II). ${ }^{24}$ A unique specimen of the libretto was found in Lvov, formerly the capital of eastern Galicia, one

pp. 185-198 (heirenafter PEGAH 2012). BOHADLO, Stanislav. Questenberg a Sporck - oddělené a nezávislé barokní hudební subkultury na Moravě a v Čechách? [Questenberg and Sporck - Separate and Independent Baroque Music Subcultures in Moravia and Bohemia?]. Musicologica Brunensia 46, 2011, iss. 1-2, pp. 15-34 (heirenafter BOHADLO 2011). ČERNÁ, Zuzana. Antonio Bioni and his compositions have been preserved in the Kroměříž archive. Musicologica Brunensia 52, 2017, iss. 2, pp. 217-242. DOI: 10.5817/MB2017-2-18.

20 Cf. in particular HOLZBAUER, Ignaz Jakob. Kurzer Lebensbegriff des Herrn Ignaz Holzbauer, kurpfälzischen Kapellmeisters. In Günther von Schwarzburg. Ed. Hermann Kretzschmar. Leipzig 1902. SEHNAL, Jiří. Ignaz Jakob Holzbauer. In Theater in Böhmen, Mähren und Schlesien.Von den Anfängen bis zum Ausgang des 18. Jahrhunderts. Ein Lexikon. Neu bearbeitete, deutschsprachige Ausgabe. Eds. Alena Jakubcová and Matthias J. Pernerstorfer [= Theatergeschichte Österreichs, Bd. X: Donaumonarchie, Heft 6], Wien - Praha 2013, pp. $288-289$. PERUTKOVÁ 2015, passim. The significance of Holzbauer's Vienna work has not yet been subjected to more thorough research and has not been assessed properly.

21 Cf. SOMMER-MATHIS 2015.

22 BENNETT, Lawrence. Ignaz Holzbauer and the origins of German Opera in Vienna. Eighteenth-Century Music 3, 2006, pp. 63-90. The score in D-MEIr, sign. Ed 130d. HOLZBAUER, Ignaz. Hypermnestra. Ed. Lawrence Bennett. Denkmäler der Tonkunst in Österreich, Bd. 157. Graz: ADEVA Musik, Akademische Druck- u. Verlagsanstalt, 2014.

23 STROHM, Reinhard. Ignaz Holzbauers Hypermnestra (1741). Zur Geschichte und Interpretation des Librettos. Studien zur Musikwissenschaft 58, 2014, pp. 133-170 (heirenafter STROHM 2014).

24 Previously, celebration in a private circle with the serenata L'amor prigioniero (P. Metastasio/G. Reutter Jr.). Score in A-Wn, Mus.Hs. 17726, the composition is labeled as Dialogo per Musica. According to Claudia Michels, however, this staging on April 3, 1741 is uncertain; MICHELS, Claudia. Opernrepertoire in Wien um 1740: Annäherungen an eine Schnittstelle. In Im Dienste einer Staatsidee: Künste und Künstler am Wiener Hof um 1740 [= Wiener musikwissenschaftliche Beiträge, Bd. 24]. Ed. Elisabeth Th. Fritz. Wien: Böhlau Verlag, 2013, pp. 125-158. After all, the conception and expected birth of the next Emperor Joseph II was reflected in music (serenata Il natale di Giove made on the occasion of the birthday of the emperor Charles VI 1740, by P. Metastasio/G. Bonno). 
of the states of the Habsburg confederacy (present-day Ukraine). ${ }^{25}$ The original German libretto - as is the case with Hypermnestra - was penned by Johann Leopold van Ghelen.

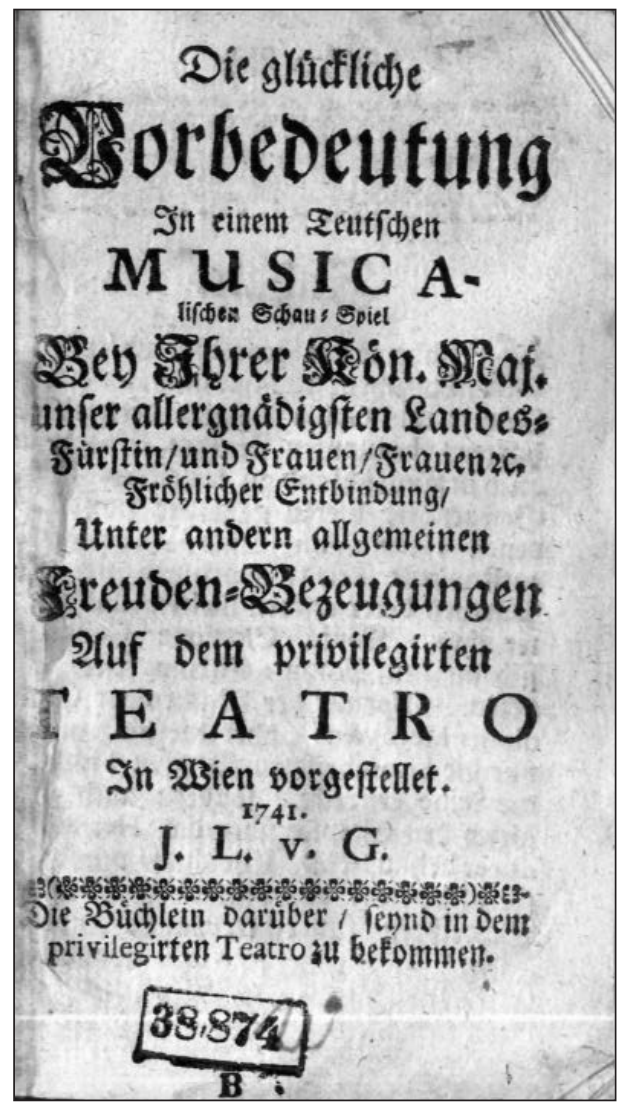

Fig. 1 Die glückliche Vorbedeutung, title page

The title page of the libretto is as follows:

Die glückliche | Vorbedeutung | In einem Teutschen | MUSICA- | lischen Schau=Spiel | Bey Ihrer Kön. Maj.| unser allergnädigsten Landes=| Fürstin, und Frauen, Frauen etc. | Fröhlicher Entbindung, | Unter andern allgemeinen | Freuden=Bezeugungen | Auf dem privilegirten | TEATRO | In Wien vorgestellet. | 1741. | J. L.v. G. [= Johann Leopold van Ghelen] | Die Büchlein darüber, seynd in dem I privilegirten Teatro zu bekommen.

25 The Libretto was identified in Lviv/Lemberg by Ondřej Macek as part of the grant project GA ČR 408/09/0334, for which I would like to thank him. It is stored in UA-LVs, sign. No. CT 66524, old call number 38.874. B. 
Johann Leopold van Ghelen (1708-1760), a lawyer and an assessor of the Imperial Vienna City and Land Court (Beisitzer des Kaiserlichen Wiener Stadt- und Landgerichts), was the son of the famous Viennese printer Johann Peter van Ghelen. He had extensive experience in translating librettos: he translated several dozen of them for the Kärntnertortheater, and as a translator and librettist he also worked for Count Questenberg, at least in 1735-1738. ${ }^{26} \mathrm{He}$ also translated librettos for Graz and Mannheim. ${ }^{27}$ Ghelen's activity for the Kärntnertortheater was characterized by Hofmeister Hoffmann in one of his letters to Questenberg. According to him, Ghelen not only had to translate all librettos to the operas staged at the Kärntnertortheater to German, but he also had to have them printed, censored and proofread. ${ }^{28}$

Like Hypermnestra, Die glückliche Vorbedeutung is based on the original Italian version, namely Demetrius by Pietro Metastasio (first set to music by Antonio Caldara in 1731). ${ }^{29}$ The author of the music, which is considered lost, is not listed in the libretto. It was Ignazio Maria Conti, as we can see from another source - the extensive ceremonial print of the Wiennerische Beleuchtungen which describes in detail the celebrations of the birth of Archduke Joseph (March 13, 1741) ${ }^{30}$ In the foreword, the authors refer to the celebrations of the birth of the first-born son of Charles VI, Archduke Leopold, in 1716. ${ }^{31}$ These celebrations were to be the model for the celebrations of the birth of the next successor to the throne, the Archduke Joseph, in honor of whom many richly illuminated festival arches and allegorical scenes ("Triumph- und Ehren-Gerüste und Sinnbilder") were created in many places in Vienna. These festivities, characterized by numerous ephemeral works of architecture, also effectively ended the days of national mourning for the death of

26 Cf. PERUTKOVÁ 2015, p. 250. Numerous Ghelen's adaptations are documented primarily in the performance of Merope, Riccardo Broschi's opera, in Jaroměřice in 1737.

27 Cf. WALTER, Friedrich. Geschichte des Theaters und der Musik am Kurpfalzischen Hofe. Hildesheim: Olms, 1968; STROHM 2014.

28 Hoffmann wrote in a letter dated September 4, 1737: "Es zweiffelt der von Ghelen gar nicht, daß Ewer Excellenz alles anständig së̈n wurde, nach deme er alle hiesige operetten verteutschen, wällisch und teutsch drucken lassen, und censurieren mus: folglich auch beÿ dieser keinen fehler unterlaufen lassen will."

29 This fact has already been noted based on the libretto provided by the author of this study, STROHM 2014. Cf. PERUTKOVÁ 2015, p. 411. Cf. also STROHM, Reinhard. Demetrio by Pietro Metastasio and Johann Adolf Hasse: a dramma per musica for Vienna and Venice. In STROHM, Reinhard - MENCHELLI-BUTTINI, Francesca (eds.). Pietro Metastasio - Johann Adolf Hasse, Demetrio. Facsimile edition of the score; edition of the libretto by Francesca Menchelli-Buttini; introductory essays by Reinhard Strohm and Francesca Menchelli-Buttini [= Drammaturgia musicale veneta, 17]. Milan: Ricordi, 2014, pp. vii-lviii.

30 Wiennerische | Beleuchtungen | Oder | Beschreibung | Aller deren | Triumph= und Ehren=Gerüsten, | Sinn=Bildern | Und anderen [...] Auszierungen, | Welche bey denen | Zu Ehren der Ho" chst= gewünschten Geburt | Des Durchleuchtigsten Ertz-Hertzogs zu Oesterreich, ec. | JOSEPHI | Den 13. Martii das erstemal, | Und sodann | Bey Allerhöchst Ihro Majestät der Königin von Hungarn | und Böheim| Ertz=Hertzogin zu Oesterreich | [...] ec. Mariæ Theresiæ Unserer Allergnädigsten Frauen Frauen | Beseegneten Hervorgang | Den 23. und 24. April zum andert= und drittenmal, allstäts Abends, und die | Nächte hindurch, nicht nur in alhiesig frohlockender Stadt Wienn, sondern auch mancher Orten | [...] zu sehen gewesen [...] Zusammen getragen [...] von Johann Peter v. Ghelen [...] Wien [...] 1741. The print has 319 pages and also contains a nonpaged index. A-ALT, call sign. 47. Nn. 194 (hereinafter Wiennerische Beleuchtungen 1741).

31 Unfortunately, Archduke Leopold died in the same year. 
Emperor Charles VI on October 20, 1740. The Wiennerische Beleuchtungen also details the production of Die glückliche Vorbedeutung. In addition to the names of its authors, it also mentions Joseph Selliers as the impresario in charge of the production. ${ }^{32}$

Composer Ignazio Maria Conti (1699?-1759) was probably born in Florence but spent most of his life in Vienna. He was the son of the imperial court composer and theorbist Francesco Bartolomeo Conti. However, he never achieved a position as important as his father's; it seems that he never obtained a court post higher than the Hofmusikscholar, ${ }^{33}$ although on title pages of some librettos dating back to 1730 he is referred to as Compositore da Camera di Sua Maestà Cesarea. ${ }^{34}$ For the Emperor's Court, he composed mainly shorter celebratory works and oratorios, as well as cantatas, masses and other sacred compositions. He was also active outside the imperial court. He gained his first experience with the composition of drammi per musica thanks to the commissions from Count Johann Adam von Questenberg. Ignazio Conti has penned at least two operas for the count, but their scores are missing: L'elezione d'Antioco in re della Siria in 1732 and $\mathrm{Il}$ delizioso ritiro scielto da Lucullo, console Romano in $1738 .{ }^{35}$ A German translation of the latter work's Italian libretto was created by Johann Leopold van Ghelen. Ghelen and Conti later also worked together. They created, for example, an oratorio performed on Good Friday, 1753, at the holy sepulchre, with the Viennese Barnabites in Michaelerkirche. The work is titled St. Paul zu Athen. ${ }^{36}$ The title page ("Ein Musicalisches Teutsches Oratorium") emphasized the fact that this was a German oratorio, but oratorios for the holy sepulchre (sepolcri) in German were in fact regularly staged by most church orders. The work by Ignazio M. Conti, in any case, still awaits a comprehensive assessment.

The print of the Wienerische Beleuchtungen from 1741 is an interesting source for various reasons. The description of the staging of Die glückliche Vorbedeutung is preceded by a detailed description of the festival arch built in front of the Kärntnertortheater

32 Margaret Dietrich informs about Wienerische Beleuchtungen and its contents. DIETRICH, Margaret. Theater am Hofe - zwischen Tradition und Wandel. In Maria Theresia und ihre Zeit. Eine Darstellung der Epoche von 1740-1780 aus Anlass der 200. Wiederkehr des Todestages der Kaiserin, 2.Aufl. Ed. Walter Koschatzky. Salzburg: Residenz Verlag, 1980, pp. 393-403.

33 He was registered in the Imperial Court calendars as Hofscholar in 1721-1740, cf. KUBISKA-SCHARL, Irena - PÖLZL, Michael. Die Karrieren des Wiener Hofpersonals 1711-1765. Eine Darstellung anhand der Hofkalender und Hofparteienprotokolle. Innsbruck - Wien - Bozen: StudienVerlag, 2013, p. 557.

34 This applies, for example, to the libretto of the oratorios Ezechia from 1733 (libretto in A-Wn, sign. 25218B), Debbora from 1734 (libretto in A-Wn, sign. 25213-B), Il figliuol prodigo 1735 (libretto in A-Wn, sign. 25209-B), Il giusto afflitto nella persona di Giobbe from 1736 (libretto in A-Wn, sign. 1810-B), and also the libretto for the opera Il delizioso ritiro scielto da Lucullo, console Romano, which I. M. Conti wrote in 1738, commissioned by Count Johann Adam Questenberg.

35 The opera was composed to the Italian libretto by impresario Filippo Neri del Fantasia, who was - in that time - settled in Brno. The German title of the work is Das von Lucullo Römischen Consul erwehlte angeneme Land-Leben. Ignazio Conti composed an unspecified composition for Count Questenberg in 1735, and Conti also provided him with several compositions written for the Imperial Court, in particular in 1736 . He also gave Questenberg the oratorios Gioseffo and Naaman, composed by his father. He used to visit Jaroměřice in person. Questenberg paid for copying of his opera Ezio for the Kärntnertortheater in Vienna in 1742 . Cf. PERUTKOVÁ 2015, passim., in particular $234 \mathrm{ff}$.

36 Libretto in A-Wn, sign. 4159-B. This libretto will be discussed in another study. 
during the celebration of Joseph's birth. ${ }^{37}$ Die glückliche Vorbedeutung is characterized as "auf dieses Freuden-volle Geburts-Fest einiger massen abzielende Teutsche Opera", followed by the description of the new magnificent theater decorations and especially the expensive costumes. ${ }^{38}$ The final scenic decoration ("sehenswürdige Verwandlung") receives a special description; the description is largely adopted from the libretto and mainly focuses on the decorative heraldic show celebrating the newly burst branch of the Habsburg tree. Under the open sky, a view opened, revealing the temple of bliss of the ancient Germanic god Thor, various coats of arms, a tree growing out of the Habsburg Lion, etc. The report ends with a description of a congratulatory finale (in the manner of the licenza), followed by a sumptuous ballet in which personifications of Austrian provinces carried heraldic shields to the general applause of the audiences.

\begin{abstract}
"Es veränderte sich nämlichen ein dem alt=teutschen heidnischen Ab-gott Thor gewidmeter Hayn / unter angenehmer Symphonie in einen offenen Himmel / worinnen man den Tempel der Glückseligkeit erblikte. Hierbey habe man in einem hellen Glanz das Burgundische / Fränkische / Thüringische / und Schwäbische Wappen / aus denen ein mit dem habspurgischen Löwen beziechneter Stamme hervor wuchse / der sich in 2. mit dem Oesterreichischen / und Lothringischen Wappen gezierte Aeste / welche wiederum durch einen Art=Geist in einen einzigen Zweig mit einem goldenen Band verbunden wurden / zertheilete. Welches nebst allem uorigen / so zur vorgesetzten Allusion dienete / ein heidnischer Priester des vorbenannten Abgotts in einem auf viele mit=stimmende Instrumenten künstlich verfasseten Madrigal erklärete / und darauf dieses ganze Theatral=Fest mit einem im Chor gesungenen Glück=Wunsch / und endlich erfolgten prächtigem Ballet von unterschiedlichen Oesterreichischen Provinzen / mit allgemeinen Beyfall beschlossen wurde; welche zuletzt ihre an denen Armen getragene Wappenschilde veränderten / und folgende Innschrift vorstelleten:

Floreat Austriadum Fertilitate Thorus. Es erzeigte sich das Allerdurchleuchtigste Oesterreichsche Stammen=Hause allstäts fruchtbar."
\end{abstract}

This last opera scene corresponded to the prologue, which is not mentioned in the Wienerische Beleuchtungen but described in the libretto. It was a scene introduced by "einer kurzen Musicalischen Entrata", an allegoric scene of sorts mixed with ballet and rich in symbolism. The personifications of the four Continents seek a shadow under the green branches of the Habsburg family tree; they admire it and dance under it. Suddenly, Time appears, trying to steal one of the branches and hide it in an ancient tombstone, which makes the Continents sad. The darkened sky, however, is lit by two stars symbolizing both parents - Maria Theresa and Franz Stephan. The Continents recover quickly from their horror, as the golden branch begins to grow from the tree. Time's evil plot is defeated by the armed (Habsburg) eagle with thunder. At the same time, heaven opens up and the eternal seat of Astrea, the goddess of justice, appears, descends to Earth, and forces Time to watch the tree in worship. The Continents watch with joy, and the prologue ends with a ballet. This introductory scene was therefore not only a celebration

37 Wiennerische Beleuchtungen 1741, pp. 273-280.

38 "neuen herrlichen Auszierungen des Theatri und diesesmal besonders kostbaren Kleidungen." Ibid. 
of the succession, but above all an allegorical manifestation of the political strength with which the Habsburg monarchy faced recent wars, as will be explained below.

As mentioned above, Ghelen's libretto to Die glückliche Vorbedeutung is largely a translation of Metastasio's Demetrius. The German libretto's descriptions of stage decorations and stage directions are literal translations of the Italian original. The only exception is the detailed description of the III/11 scene, which corresponds to the III/12 scene of Metastasio's original. Ghelen's libretto changed Metastasio's Tempio (Temple) to Hayn (Grove) to accent Germanic mythology.

The description of the entire scene III/11 is as follows:

\begin{abstract}
"Ein angenehmer dem Gott Thor gewidmeter Hayn mit einem Altar vor diesem Abgott (welcher gecrönt) und mit zwölf Sternen umgeben auf einer Kiste sitzet, und auf der Seite ein Thron. Auf die letzt verändert sich der Hayn unter einer angenehmen Symphonie in einen offenen Himmel, worinnen man den Tempel der Glückseeligkeit blicket. Anbey sihet [sic!] man in einem hellen Glantz das Burgundische, Fränckische, Thüringische, und Schwäbische Wappen, aus denen ein mit dem habspurgischen Löwen bezeichneter Stamm hervor machet, der sich in zwey mit dem Oesterreichischen und Lotharingischen Wappen gezierte Aeste vertheilet, welche wiederum durch einen Genium in einen einzigen Zweig mit einem goldenen Band verbunden werden."
\end{abstract}

Some of Metastasio's recitatives were shortened in Glückliche Vorbedeutung, several arias were omitted, several paraphrased or written anew, some scenes were completely deleted (see Tab. 1). Out of Metastasio's 29 numbers, only 20 have been left by Ghelen..$^{39}$

The story was moved from Syria to Germania. The characters have newly created German names. In Ghelen's version, Metastasio's main heroine Cleonice becomes Engeltrida, the queen of two Germanic tribes of Hermundur and Sigambri. The future King Alceste/Demetrio is named Rambertus/Merbizius in Glückliche Vorbedeutung; likewise, Barsene, Cleonices's girlfriend is Rothilda, Alcesto's rival Olinto is Gosbertus, Alcesto's guardian and Olint's father Fenicio is Theodowald, Prince of Burgundy; Governor Mitrane is in Ghelen's version nobleman Wasinus. Glückliche Vorbedeutung also introduces one entirely new character - Othin, who heads the German troops and bards. He only performs in the last scene (licenza). The supporting cast consists of Celtic ambassadors, noble people of the empire, soldiers, druids and servants.

The title of the opera appears in the final recitative: after explaining all the twists and turns of the plot, Theodowald summarizes: "So lasset uns bey so beglückten Vorbedeutungen / nunmehro dann zu dem Genuß / so süsser Hofnung [sic!] schreiten."

The opera Die glückliche Vorbedeutung premiered at the Kärntnertortheater in the spring of 1741 together with several other serious German operas. We shall return to the reasons behind the 1741 focus on German opera in more detail later.

39 Exact comparison cannot be done by the number of verses - the German translation is almost literal, but one Italian endecasillabo is often elaborated into two or more German verses. 


\section{Table $\mathbf{1}^{40}$}

Legend:

In the column devoted to the German version, the equal sign means that the German recitatives and arias are direct translations from Italian. The Table also explains which of the arias in the German version were modified, replaced or newly inserted, and which Italian arias were cut.

$\begin{array}{ll}\text { Cleonice (Cle) } & \text { Engeltrida (Engel) } \\ \text { Alceste (Alc) } & \text { Rambertus (Ramb) } \\ \text { Fenicio (Fen) } & \text { Theodowald (Theod) } \\ \text { Olinto (Ol) } & \text { Gosbertus (Gosb) } \\ \text { Barsene (Bar) } & \text { Rothilda (Roth) } \\ \text { Mitrane (Mit) } & \text { Wasinus (Was) }\end{array}$

\begin{tabular}{|c|c|}
\hline Demetrio, Vienna 1731 & Die glückliche Vorbedeutung, Vienna 1741 \\
\hline $\begin{array}{l}\text { I/1 } \\
\text { Di quell' ingiusto sdegno // Tu mi rendesti amante } \\
\text { (Ol) }\end{array}$ & $\begin{array}{l}=1 / 1 \\
\text { Du zörnest dich // Dein Antlitz Selbst ist Schuld da- } \\
\text { ran (Gosb) }\end{array}$ \\
\hline $\mathrm{I} / 2$ & $=1 / 2$ \\
\hline $\begin{array}{l}\text { I/3 } \\
\text { Fra tanti pensieri // Le cure del soglio (Cle) }\end{array}$ & $=1 / 3$, no aria \\
\hline $\begin{array}{l}\text { I/4 } \\
\text { Misero tu non sei // Misera ben son io (Bar) }\end{array}$ & $\begin{array}{l}=1 / 4 \\
\text { Du bist nicht elend, nein // Elend bin zu nennen } \\
\text { (Roth) }\end{array}$ \\
\hline $\begin{array}{l}\text { I/5 } \\
\text { Ogni procella infida // Virtù fedel mi rende (Fen) }\end{array}$ & $=I / 5$, no aria \\
\hline $\begin{array}{l}\text { I/6 } \\
\text { Alma grande e nata ale regno // Come il foco in } \\
\text { chiuso loco (Mit) }\end{array}$ & $\begin{array}{l}=1 / 6 \text {, a new aria (not paraphrased) } \\
\text { Die Flamme laß den Schimmer // Wie soll alsdann } \\
\text { bey edlen Seelen (Was) }\end{array}$ \\
\hline $\begin{array}{l}\text { I/7 } \\
\text { Ogni nume, ed ogni diva (Coro) }\end{array}$ & $=\mathrm{I} / 7$, without the introductory chorus \\
\hline $\begin{array}{l}\text { I/8 } \\
\text { Se libera non sono // A chi servendo impera (Cle) }\end{array}$ & $\begin{array}{l}=1 / 8 \text {, a new aria } \\
\text { Ihr beglükte Bauerinnen // Warum habit ihr in die- } \\
\text { sem Stücke } \\
\text { A printing error in the recitative preceding the aria. } \\
\text { Before the text "Das ganze Volk soll }[. . .]^{\prime} \text { Engeltri- } \\
\text { da should be mentioned as the speaker, who also } \\
\text { sings the following aria (not Theodowald). }\end{array}$ \\
\hline $\begin{array}{l}\text { l/9 } \\
\text { Se fecondo e vigoroso // Ma da lui rivolge il piede } \\
\text { (Fen) }\end{array}$ & $\begin{array}{l}=1 / 9, \\
\text { Des Gärtners treue Hand/Befremdt es dich (Theod) } \\
\text { The A-part of the aria is a paraphrase or free trans- } \\
\text { lation, but the B-part is a new text that elaborates } \\
\text { on the idea of the A-part, regardless of the original } \\
\text { B-part. }\end{array}$ \\
\hline
\end{tabular}

40 I am grateful to Ondřej Macek for his help with the comparison of the librettos to Die glückliche Vorbedeutung and Aristheus. 


\begin{tabular}{|c|c|}
\hline Demetrio, Vienna 1731 & Die glückliche Vorbedeutung, Vienna 1741 \\
\hline \begin{tabular}{|l|} 
I/10 \\
Scherza il nocchier talora // Non cura il pellegrino \\
(Alc)
\end{tabular} & deleted \\
\hline $\begin{array}{l}\text { I/11 } \\
\text { Che mi giova l'onor della cuna // Cieca diva non } \\
\text { curo il tuo dono (OI) }\end{array}$ & deleted \\
\hline $\mathrm{I} / 12$ & $=I / 10$ \\
\hline $1 / 13$ & $=\mathrm{l} / 11$ \\
\hline \begin{tabular}{|l} 
I/14 \\
Dal suo gentil sembiante // Ogni beltà più rara (Alc)
\end{tabular} & $\begin{array}{l}=1 / 12, \\
\text { Die Sehnsucht, so für sie // Sie ist die erste Pein } \\
\text { (Ramb) } \\
\text { Rambert's aria is a paraphrase of Alceste's aria. } \\
\text { The endings of the Italian Scenes } 13 \text { and } 14 \text { (Deme- } \\
\text { trio) are modified in the German Scene } 11 \text { (Vorbe- } \\
\text { deutung), so that Rambertus remains alone in } \\
\text { Scene } 12 \text { (= Demetrio 14), and thus his aria ends } \\
\text { the first act, whereas in Demetrio the act ends with } \\
\text { Barsene's aria (Vorrei dai lacci sciogliere, } 1 / 15 \text { ). }\end{array}$ \\
\hline $\begin{array}{l}\text { I/15 } \\
\text { Vorrei dai lacci sciogliere // No, dell'altrui tormento } \\
\text { (Bar) }\end{array}$ & deleted \\
\hline $\mathrm{II} / 1$ & $=\mathrm{II} / 1$ \\
\hline \begin{tabular}{|l|} 
II/2 \\
Non v'è più barbaro // Gli astri m'uccidano (Alc) \\
\end{tabular} & $=\| I / 2$, no aria \\
\hline $\begin{array}{l}\text { II/3 } \\
\text { É la fede degli amanti // Se tu sai dov'ha ricetto (OI) }\end{array}$ & $\begin{array}{l}=11 / 3 \\
\text { Dass es einen Phoenix gebe // Was the nun bei die- } \\
\text { sen Zeiten (Gosb) }\end{array}$ \\
\hline $\begin{array}{l}\text { II/4 } \\
\text { Dice, che } t^{\prime} \text { è fedele // Che ti vedrà placata (Mit) }\end{array}$ & $\begin{array}{l}\text { = II/4 } \\
\text { Er sagt, dass er es nicht verstehe // Er sagt, von dir } \\
\text { entfernt zu sein (Was) }\end{array}$ \\
\hline $\mathrm{II} / 5$ & $=I I / 5$ \\
\hline $\mathrm{II} / 6$ & $=11 / 6$ \\
\hline $\begin{array}{l}\text { II/7 } \\
\text { Nacqui agli affanni in seno // Perdo la mia costanza } \\
\text { (Cle) }\end{array}$ & $=\| / 17$, no aria \\
\hline $\mathrm{II} / 8$ & $=11 / 8$ \\
\hline $\begin{array}{l}\text { II/9 } \\
\text { So che per gioco // A un altro oggetto (Bar) }\end{array}$ & $\begin{array}{l}=\| 1 / 9 \\
\text { Ich weiß, dass diese Gnad // Ich habe selbst auch } \\
\text { wol }^{41} \text { (Roth) }\end{array}$ \\
\hline $\begin{array}{l}\text { II/10 } \\
\text { Non fidi al mar che freme // Non si cimenti in cam- } \\
\text { po (Ol) }\end{array}$ & $\begin{array}{l}=\| / 10 \text {, no aria } \\
\text { Incorrect character designation in the libretto - } \\
\text { correctly "Gosbertus allein", not Wasinus. }\end{array}$ \\
\hline $\mathrm{II} / 11$ & $=\| \mathrm{I} / 11$ \\
\hline $\begin{array}{l}\text { II/12 } \\
\text { Non so frenare il pianto // È meraviglia, è amore } \\
\text { (Alc) }\end{array}$ & $\begin{array}{l}=\| / 12 \\
\text { Da meine Seele mich verläst // Ich spür' Verwunde- } \\
\text { rung, Lieb und Reu (Ram) }\end{array}$ \\
\hline
\end{tabular}

41 In the incipits within the Table I and Table II, the original literal transcription including press errors is kept. 
Die glückliche Vorbedeutung and Aristheus: Unknown Libretti of German-Language Operas ...

\begin{tabular}{|c|c|}
\hline Demetrio, Vienna 1731 & Die glückliche Vorbedeutung, Vienna 1741 \\
\hline $\begin{array}{l}\text { II/13 } \\
\text { Manca sollecita // Se consolarmi voi non potete } \\
\text { (Cle) }\end{array}$ & $\begin{array}{l}=\mathrm{II} / 13 \\
\text { Warum wollt ihr meinem Herzen // Wisst ihr nicht, } \\
\text { dass eine Kerzen (Engel) } \\
\text { The aria is a free translation, but parts A and B have } \\
\text { been swapped. }\end{array}$ \\
\hline $\begin{array}{l}\text { II/14 } \\
\text { Saria piacer, non pena // Ma quando s'innamora } \\
\text { (Bar) }\end{array}$ & $=\mathrm{II} / 14$, without aria \\
\hline $\begin{array}{l}\text { II/15 } \\
\text { Disperato in mar turbato // E venuti i dì felici (Fen) }\end{array}$ & $\begin{array}{l}=1 \mathrm{I} / 15 \\
\text { Endlich trifft der Wanders-Mann // Sein Vergnügen } \\
\text { ist dann grösser (Theod) }\end{array}$ \\
\hline $\mathrm{III} / 1$ & $=\mathrm{III} / 1$ \\
\hline $\begin{array}{l}\text { III/2 } \\
\text { Pensa che sei crudele // Rammenta il dolce affetto } \\
\text { (Fen) }\end{array}$ & $=I I I / 2$, no aria \\
\hline $\begin{array}{l}\text { III/3 } \\
\text { lo so qual pena sia // Allor che t'abbandono (Cle) }\end{array}$ & $\begin{array}{l}\text { = III/3, a completely different aria } \\
\text { Ich weiß wol, was für Pein, und Schmerzen // } \\
\text { Erzeig' dich mich (Engel) }\end{array}$ \\
\hline $\begin{array}{l}\text { III/4 } \\
\text { Quel labro adorato // Non ama da vero (Alc) }\end{array}$ & $=I I I / 4$, without aria \\
\hline $\begin{array}{l}\text { III/5 } \\
\text { Più non sembra ardito e fiero // Ma se un giorno } \\
\text { i lacci spezza (Ol) }\end{array}$ & $\begin{array}{l}=111 / 5 \\
\text { Wann der Löw schon lang gebunden // Ob er } \\
\text { manchmal gleich verschonet (Gos) }\end{array}$ \\
\hline III/6 & $=I I I / 6$ \\
\hline $\mathrm{III/7}$ & $=\mathrm{III} / 7$ \\
\hline $\begin{array}{l}\text { III/8 } \\
\text { Giusti dei da voi non chiede // Fato reo, felice sorte } \\
\text { (Fen) }\end{array}$ & $\begin{array}{l}=\mathrm{III} / 8 \\
\text { Nun ist das Ziel // Ich sterbe nun vergnügt, und } \\
\text { gerne (Theod) } \\
\text { The aria is a paraphrase. }\end{array}$ \\
\hline $\begin{array}{l}\text { III/9 } \\
\text { Più liete imagini // Avvezzo a vivere (Mit) }\end{array}$ & deleted \\
\hline $\begin{array}{l}\text { III/ } 10 \\
\text { Se tutti i miei pensieri // Non ti sdegnar se poco } \\
\text { (Alc) }\end{array}$ & $\begin{array}{l}=111 / 9 \text {, only the beginning of the recitative is from } \\
\text { Dem III/9 } \\
\text { Solltest du mein Herz erkennen // Dann ob schon } \\
\text { ich (Ram) }\end{array}$ \\
\hline $\begin{array}{l}\text { III/11 } \\
\text { Semplicetta tortorella // Voglio anch'io fuggir la } \\
\text { pena (Bar) }\end{array}$ & $\begin{array}{l}\text { = III/10 } \\
\text { Die Taube, so behutsam will // So eben ist es mei- } \\
\text { nem Herz (Roth) }\end{array}$ \\
\hline III/12 & = III/11, changed scene description (see above). \\
\hline $\begin{array}{l}\text { III/13 } \\
\text { Deh risplendi o chiaro nume (Alc, Cle) }\end{array}$ & $\begin{array}{l}\text { = III/12, a completely different duet } \\
\text { Helle Gottheit, lass dem Triebe (Ram, Engel) }\end{array}$ \\
\hline $\begin{array}{l}\text { III/14 } \\
\text { Quando scende in nobil petto // Respirate alme } \\
\text { felici (Coro) }\end{array}$ & $=I I I / 13$, without the chorus \\
\hline $\begin{array}{l}\text { III/15 (Ultima) } \\
\text { Per te con giro eterno // Ma quella che ritorna (Li- } \\
\text { cenza) }\end{array}$ & $\begin{array}{l}=\text { III/14 (Ultima) Es steige / Der Zweige (Chorus) } \\
\text { After the reading of the letter, the scene is modi- } \\
\text { fied, in that Othin comes on stage and a homage } \\
\text { to the German realm follows. } \\
\text { An entirely different chorus. }\end{array}$ \\
\hline
\end{tabular}




\title{
Aristheus
}

The libretto to Aristheus has not been previously discussed in scholarly literature; it was identified by the author of this study in 2016. However, the circusmtances of the work's 1741 performance raise numerous questions for future study. At present, three copies of the libretto are known. The title page of all three exemplars emphasize the production of the opera in the Styrian capital of Graz. ${ }^{42}$

The title page states the following:

ARISTHEUS | In einer Teutschen | OPERA | Vorgestellet | In Grätz, | Und | Einer hochlöblichen | In. Oe. Regierung | Und | Hof=Cammer | In tieffester Veneration | dediciret 1741. | Diese Büchlein seynd in dem Comoe- $\mid$ die=Haus zu bekommen.

The title is followed by the usual dedication to the government of Inner Austria, the court chamber and the governor of Styria, Karl Adam Anton Count Breuner von Stübing-Fladnitz at that time ("Innerösterreichische Regierung und Hofkammer und den Statthalter"). The dedication is as follows:

\begin{abstract}
"Sich um die Genehmhaltung deren Grossen bewerben, ist ein vernünftiger Ehrgeiz derjenigen, welche sich durch bemüheten Kunst-Fleiß suchen beliebt zu machen. Aristheus erscheinet alhier zum erstenmal in einer Teutschen Opera auf dem nunmehro nach erforderlichen Umständen best-möglichst eingerichten Theatro, und leget Euer Hoch=Gräfl[ichen] Excellenz, Gnaden, und Gnaden, etc. etc. sich submissest zu Fussen, Dero Hohen Schutz und Gnade sowohl für sich als andere noch ferners vorkommende Materien zu erhalten. In solchergebenster Zuversicht unterwerffen sich mit ersinnlichstem Respect Euer HochGräfl[ichen] Excellenz, Gnaden und Gnaden etc. etc. Die unterthänigst-gehorsamste Interessanten."
\end{abstract}

As can be seen, name of the impresario is missing here, instead the dedication only refers to "Interessanten" (supplicants).

However, the copy of the libretto stored in A-Wn differs from the others in one essential fact. The three introductory pages with a cover letter and a dedication to Graz were bound to this printed libretto only additionally (including one blank page, two sheets were added in total). Behind them is another title page that locates the staging to the Vienna Kärntnertortheater:

Aristheus | In einer Teutschen OPERA | Auf dem Königl. privilegierten | THEATRO | In Wien | Vorgestellet | 1741. | Die Büchlein darüber, seynd in dem | Comödien=Haus zu bekommen.

42 A-Wn, sign. 26054-A. A-Gl, sign. 156904 I. US-Dmu, sign. Jantz B 12mo \# 3406 no. 5 [2972] c.1. Storage of a copy in Graz is supported by the fact that the work was actually performed in Graz. 


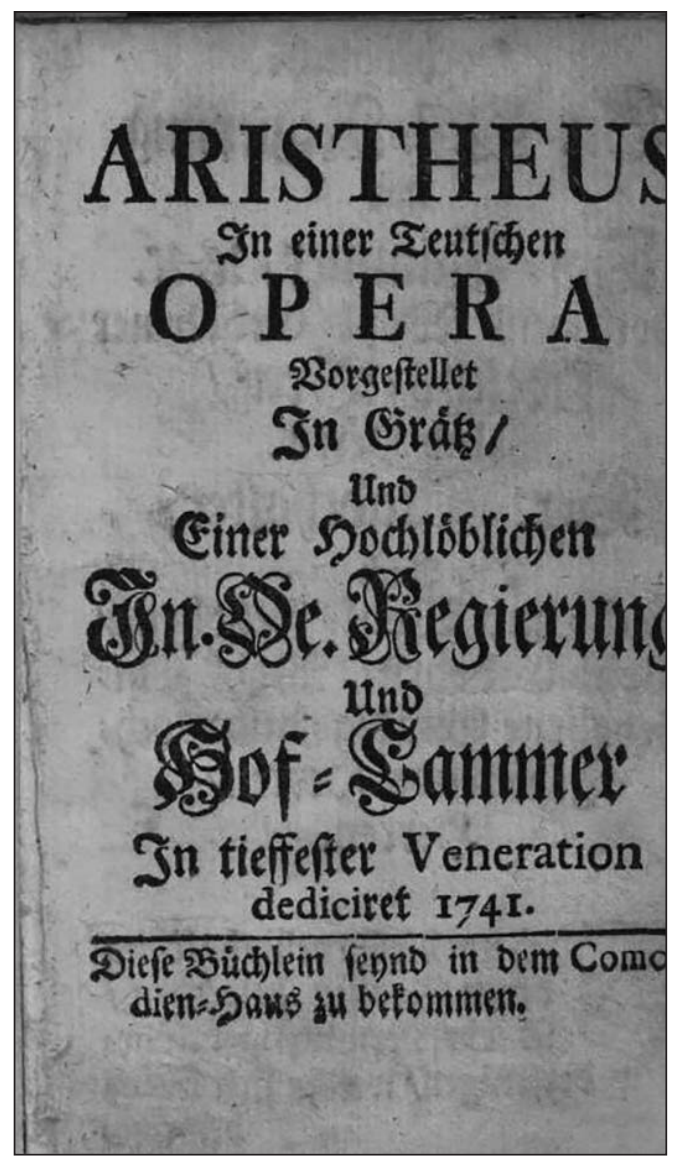

Fig. 2 Aristheus, A-Wn, sign. 26054-A, fol. 1

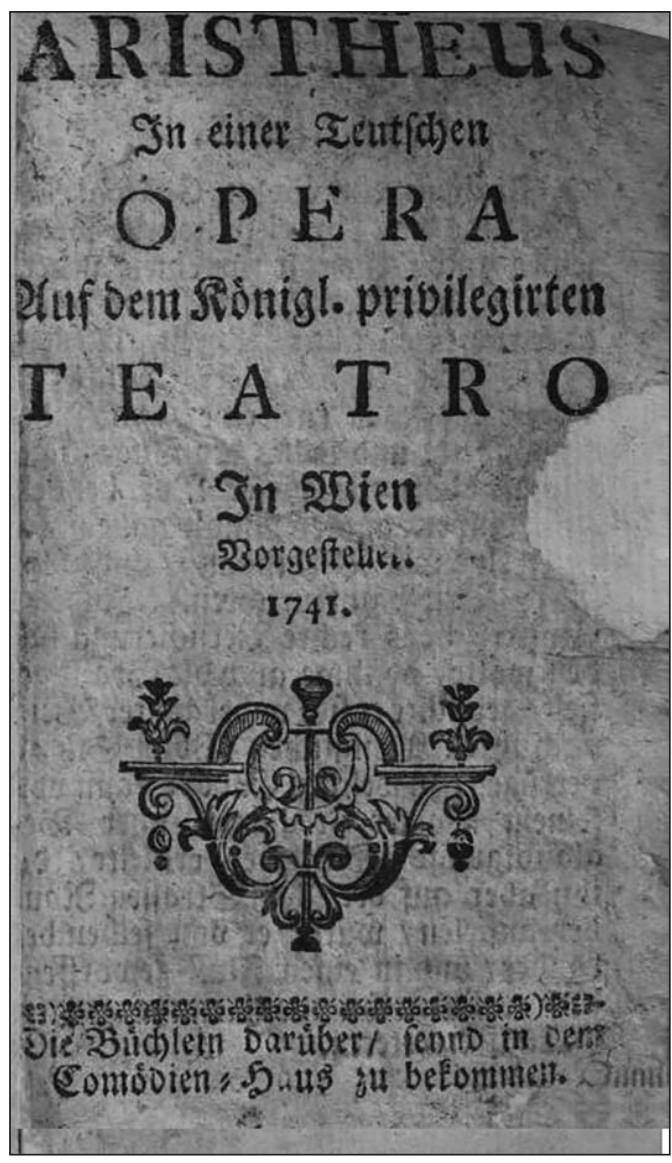

Fig. 3 Aristheus, A-Wn, sign. 26054-A, fol. 3

It follows that Aristheus was not originally intended to be staged in Graz, but in Vienna. It is likely that this copy was left in the Kärntnertortheater after the staging, and to make it usable again, the two above-mentioned sheets were attached to it in the Styrian capital. The other two preserved copies were apparently printed directly for the Aristheus production in Graz. Apart from the tile page for the Kärntnertortheater performance, all three copies are identical.

The opera Aristheus can be considered another dramma per musica, performed in Vienna in 1741, but also the first opera in German performed in Graz, as shown in the dedication. The Graz production must have been carried out by Viennese artists who had premiered Aristheus at the Kärntnertortheater. The operatic life in Graz in the spring of 1741 was stagnant because Pietro Mingotti and his operatic company stayed in Pressburg on the occasion of the session of the Hungarian Provincial Assembly and the coronation of Maria Theresa as the Hungarian Queen on June 25, 1741. The Kärntnertortheater opera ensemble apparently took advantage of this situation and staged 
Aristheus in Graz as a guest performance, although they did not normally do so. This would have been during the period when the Viennese imperial court attended the Hungarian coronation ${ }^{43}$ The staging of the opera by Viennese artists would also explain why the dedication is signed only by the indefinite expression "Interessanten". And finally, the phrase from the dedication that this German opera will be performed according to the necessary circumstances of the best equipped theater available ("[...] auf dem nunmehro nach erforderlichen Umständen best=möglichst eingerichten Theatro [...]”) probably means that the visiting Viennese artists tried to make the most of the existing theater equipment at Tummelplatz as they probably did not bring their own decorations from Vienna. ${ }^{44}$

The libretto does not mention the authors of the poetry and music. The authors are not identifies in any other known archival sources, and contemporary magazines - Wienerisches Diarium or Gräzer Mercur - do not even mention the production. The authorship therefore hypothetical. The text is, once again, a translation, or, to be more precise, an adaptation of an Italian original, as shown below. The libretto was probably written by Johann Leopold van Ghelen, who authored two similar texts (Hypermnestra, Die glückliche Vorbedeutung) in 1741, and who undoubtedly had the most experience with this type of work. Nevertheless, it is conspicuous that his name or at least his characteristic initials, left in many libretto translations, are nowhere to be found in Aristheus. It was ten years since the death of the most experienced author of German texts, Heinrich Rademin; other potential librettists of Aristheus could be either the actor, principal and translator Andreas Weidner ${ }^{45}$ or Franz Joseph Pircker, who translated the Italian libretto into German for Mingotti, and, before working for Mignotti, had been active at the Kärntnertortheater as a violinist, Musikdirektor and the composer of the opera Bacco trionfante dall'Indie (1728). ${ }^{46}$ The authorship of the music is even more obscure. Considering the experience necessary for writing such an extensive score, two composers, Ignaz Holzbauer and Ignazio Maria Conti, come to mind. Anton Phuniak, who had previously composed one opera in 1728 for the Kärntnertortheater (Atalanta) and who was the Instructor in der Musik for the Archduke Maria Theresa and her sister Marie Anne and in close contact with the imperial court, cannot be ruled out either. ${ }^{47}$ Among the composers for

43 The staging in the presence of the Empress dowager Elisabeth Christine and her daughters, Maria Anna and Magdalena, who stayed in Graz in the autumn (October 20, 1741), seems to be improbable, since Mingotti was back in Graz again. My gratitude to Andrea Zedler for information about Empress dowager's stay there from the Posttäglich Grätzerisch Außfliegenden Mercurius (Grätzer Merkur).

44 The hypothesis that an ephemeral theater was set up in Graz for the performance of Aristheus seems unlikely. On the Graz production of the opera, see also ZEDLER, Andrea - PERUTKOVÁ, Jana. "opera politica” - Grazer Opernaufführungen im Spannungsfeld der Pragmatischen Sanktion. In print. Paper presented at the Symposium Musik in Österreich von 1564 bis 1740, held on Dec 7-9, 2017, in Graz.

45 Cf. RUDIN, Bärbel. Wien - Berlin - Riga: Commedia dell'arte auf Wanderschaft: Andreas Weidner, Johann Peter Hilverding und "Die entsetzlichen Zufälle in Glück- und Unglückswechsel". In Im Spiegel der Theatergeschichte: deutschsprachiges Theater im Wechsel von Raum und Zeit. Eds. Paul S. Ulrich, Gunilla Dahlberg and Horst Fassel. Münster: LIT Verlag, 2015, pp. 21-59; PERUTKOVÁ 2015, pp. 252-253 and passim.

46 From 1736 Franz Pircker worked as Kapellmeister with the Mingotti brothers in Graz; it is assumed that he was active in the Kärntnertortheater until this year. Cf. SOMMER-MATHIS 2015.

47 FASTL, Christian - HILSCHER, Elisabeth. Th. Phuniak (Phuniack, Funiak), Anton. In Oesterreichisches 
whom German was the mother tongue, Johann Ignaz Beyer might be considered as the author as well, through he was in Pressburg in the spring of 1741 as a harpsichordist for Mingotti. ${ }^{48}$ At that time, Antonio Bioni also lived in Vienna ${ }^{49}$ but it is doubtful that this native Italian speaker would set a German libretto to music, although he had come into contact with German language during his long stay in Central Europe. The opera could also be a pasticcio, but it was undoubtedly easier to write new music to a German text (on the difficulties with substituting German text to music written to an original Italian libretto - see above).

As for the libretto, the situation is analogous to that of Glückliche Vorbedeutung and Hypermnestra. The starting point for Aristheus is an Italian text produced by the librettist Giovanni Cesar Corradi in 1700. This libretto was set to music by Antonio Polarollo for the Teatro San Cassiano in Venice. ${ }^{50}$ The only other known production based on this libretto was that by Antonio Denzio's opera company in Prague in 1729. ${ }^{51}$ However, this was a pasticcio that was fundamentally different from Corradi's libretto. And it was precisely this Prague libretto that became the model for Aristheus staged in 1741 in the Kärntnertortheater and Graz (see Tab. 2).

Aristeo, the heir to the throne of Thrace, who is as beautiful as Adonis and as strong as Mars, is going to court the beautiful and virtuous Doriclea, the sister of the king of Thebes. A group of robbers, headed by Pallamedes assaults Aristeo and throws him into a river. Pallamedes steals Aristeo's identity to win Doriclea for himself. However, Aristeo survives and comes to Doriclea's court. His identity could be confirmed by Prince Sitalce, who has known Aristeo in the past. But Sitalce betrays Aristeo and pretends not to recognize him because he himself is in love with Doriclea. Only through true love is Pallamedes' deception, with which he tried to unjustly steal the throne, finally revealed.

Theare is no need for a comparison of the original Venetian version from 1700 to the Prague version from 1729. The Prague libretto can actually be considered a new text (perhaps created by Antonio Denzio) based on Corradi's libretto. The lyrics in the recitatives are identical in some scenes, especially in the monologues, but the dialogues were to a large extent replaced by a new text. Several scenes have been left out or moved. Whereas in the Venetian libretto the first act has 17 scenes, the second 16 and the third 15 , a total of 48 scenes in the entire opera, the 1729 Prague libretto has a total of 35 scenes $(12+9+14)$. There is also a subtle difference in the plot: whereas in the 1700 Venetian libretto, Aristeo is attacked by robbers and left in the forest to be eaten by wild

\footnotetext{
Musiklexikon online, access 11.6. 2018, https://www.musiklexikon.ac.at/ml/musik_P/Phuniak_Anton.xml. Cf. also KUBISKA-SCHARL, Irena - PÖLZL, Michael. Die Karrieren des Wiener Hofpersonals 1711-1765. Eine Darstellung anhand der Hofkalender und Hofparteienprotokolle. Innsbruck - Wien - Bozen: StudienVerlag, 2013 , p. 666. 48 As Beyer himself stated, "[...] so dann aber beÿ der opera in Preschburg zur Zeit der Crönung Ihro anjetzo regierender Kä̈ser=Königl: Mäyst[ät] auf dem Clavi Cembalo accompagniret, [...].” SOkA Olomouc, Sg. Eg3, carton 1458, inventorial number 3328.

49 Cf. PEGAH 2012.

50 SARTORI, Claudio. I libretti italiani stampa dalle origini al 1800. Catalogo analitico con 16 indici. Cuneo 1990-1994, Nr. 2647. Libretto in I-Mb, RACC.DRAM.0763.

51 SARTORI Nr. 2648. Libretto in Cz-Pu, sign. 65 D 12, original provenance: Lobkowicz Library.
} 
Part A: Doricle, Aristeo à $2+$ Gilde, Sitalce à $2+$ Ballo

Part A' (à 4) - Ballo

Part B: Gilde, Sitalce à 2 + Doricle, Aristeo à $2+$ Ballo

Part B' (à 4) - Ballo

In 1729, only part A (Coro) is set to music, it is therefore a common form of the final chorus from the 1720s-1730s.

The 1741 German version of Aristheus is, as mentioned above, a more or less faithful translation of the 1729 Prague text. The Argomento, the descriptions of scenic decorations and the scenic notes are literal translations. The only difference is the omission of Clito in 1741. In the Prague version, Clito is a minor role of a member of Pallamedes' robber gang; genre-wise, he represents a comic servant (and therefore is a relic from the original Venetian work). In the 1741 opera, Clito's role was replaced with supernumenaries, his arias and a few recitative lines were cut. With the exception of Clito's line, the recitatives were shortened only minimally in 1741. The Vienna/Graz version, however, has fewer numbers, as shown in Tab. 2. 
The legend is the same as in Table 1

\section{Table 2}

Evander, Evander (Ev)

Doricle, Doriclis (Dor)

Gilde, Gildis (Gil)

Aristeo, Aristheus (Aris)

Sitalce, Sitalces (Sit)

Pallamede, Pallamedes (Pall)

Clito (Cli)

\begin{tabular}{|c|c|}
\hline Aristeo, Prague 1729 & Aristheus, Vienna - Graz 1741 \\
\hline $\begin{array}{l}\text { I/1 } \\
\text { Le rapine dell' altitonante // Egli amante - Or di } \\
\text { questa, or di quella (Cli) }\end{array}$ & $=\mathrm{I} / 1$ no aria \\
\hline $1 / 2$ & $=1 / 2$ \\
\hline $\begin{array}{l}\text { I/3 } \\
\text { Folgorante entro la Reggia // Tal che tema se si } \\
\text { veggia (Ev) }\end{array}$ & $\begin{array}{l}=\mathrm{I} / 3 \\
\text { Das schimmern der glänzenden Stralen // Daß er } \\
\text { auch wird müssen bekennen (Ev) }\end{array}$ \\
\hline $\begin{array}{l}\text { I/4 } \\
\text { Giurai - D'amanti // Ma tu crudele (Gil) }\end{array}$ & $\begin{array}{l}=1 / 4 \\
\text { Ich hab dir Lieb geschworen // Du aber wilst nie } \\
\text { lieben (Gil) }\end{array}$ \\
\hline $\begin{array}{l}\text { I/5 } \\
\text { Di quel bel sen di neve // E non dispero, un giorno } \\
\text { (Dor) } \\
\text { There is an error in the Italian version of the } \\
\text { libretto, the aria is not sung by Doricle, but by } \\
\text { Sitalce, as is rightly mentioned in the raw German } \\
\text { translation. }\end{array}$ & $\begin{array}{l}=\mathrm{I} / \mathrm{5} \\
\text { Keine Noht, hemmet dies mein heisses brennen // } \\
\text { Vielleicht daß das Glück einst schicket (Sit) }\end{array}$ \\
\hline $\begin{array}{l}\text { l/6 } \\
\text { Morir, ma non pregar // Che al fin, se l'uno avrà } \\
\text { (Dor) }\end{array}$ & $\begin{array}{l}=1 / 6 \\
\text { Ein Frauen-Zimmer, dass verliebt // Dann ist von } \\
\text { Diamant ein Herz (Dor) } \\
\end{array}$ \\
\hline $\begin{array}{l}\text { I/7 } \\
\text { Già parmi veder // E questo piacer (Aris) }\end{array}$ & $\begin{array}{l}=1 / 7 \\
\text { Es scheinet, daß in meinem Herzen // Und dieser } \\
\text { ungemeine Triebe (Aris) }\end{array}$ \\
\hline $1 / 8$ & $=1 / 8$ \\
\hline $\begin{array}{l}\text { I/9 } \\
\text { Di gigli, e di rose // E mentre, ch'io godo (Ev) }\end{array}$ & $=1 / 9$ no aria \\
\hline $\begin{array}{l}\text { I/10 } \\
\text { Perche, o vezzosa (Pall, arioso, l/10) } \\
\text { Sarai I'Ape fortunata // Goderai quel vago labro } \\
\text { (Sit) }\end{array}$ & $\begin{array}{l}=\mathrm{I} / 10 \text { without Pallamedes' cavatine in the middle } \\
\text { of the scene and without the arias of Sitalce at the } \\
\text { end. }\end{array}$ \\
\hline $\begin{array}{l}\text { I/11+ I/12 } \\
\text { Se m'insulti ò cieco Dio //E se mai legge tiranna } \\
\text { (Gil) } \\
\text { Ha sol d'avermi Sposa // Giammai non cesserò } \\
\text { (Gil) }\end{array}$ & $\begin{array}{l}=1 / 11 \\
\text { Blinde Lieb/wer dir vertraut // Doch wil man an dir } \\
\text { sich rächen (Gil) } \\
\text { This is the final scene in Act } 1 \text {, while the Doriclea } \\
\text { and Gilde dialogue from the Prague version of } \\
1729 \text { is turned into the Doriclea' monologue. The } \\
\text { scene and the act are concluded by her aria, which } \\
\text { is different from I/12 in the Prague version. In Part } \\
\text { A, in the Prague version of } 1729, \text { she sings about } \\
\text { Amor as a blind deity (cieco Dio), in the } 1741 \text { ver- } \\
\text { sion about blind love, but the content of other } \\
\text { verses differs. }\end{array}$ \\
\hline
\end{tabular}


Die glückliche Vorbedeutung and Aristheus: Unknown Libretti of German-Language Operas ...

\begin{tabular}{|c|c|}
\hline Aristeo, Prague 1729 & Aristheus, Vienna - Graz 1741 \\
\hline $\begin{array}{l}\text { II/1 } \\
\text { Il dir, che rassomigli // Perche non dassi fior (Aris) } \\
\text { Sospira, e piangi // Lieta li stendi (Ev) }\end{array}$ & $\begin{array}{l}\text { = II/1 } \\
\text { Jenes holde Angesicht // Dann, obschon der Blu- } \\
\text { men Pracht (Aris) } \\
\text { Hemme deiner Thränen Lauf // Dieses, was der } \\
\text { Himmel schickt (Ev) } \\
\text { Evander's aria in the middle of the scene is a para- } \\
\text { phrase or a very free translation. }\end{array}$ \\
\hline $\begin{array}{l}\text { II/2 } \\
\text { A miei voti Amor risponda // Ciò, ch'io vuò tù Ciel } \\
\text { m'intendi (Dor) }\end{array}$ & $\begin{array}{l}=\| l / 2 \\
\text { Treibt der Sturm jene Wellen // Läst auf gleiche } \\
\text { Art die Lieb (Dor) } \\
\text { The aria is a paraphrase. }\end{array}$ \\
\hline $11 / 3$ & $\begin{array}{l}\text { The I = I/3 scene is substantially truncated, the } \\
\text { Pallamedes' monologue without the omitted } \\
\text { Clito. }\end{array}$ \\
\hline $\begin{array}{l}\text { II/4 } \\
\text { Lo scherzar - Lice tal ora // Chi trascende - quelle } \\
\text { mete (Gil) }\end{array}$ & $\begin{array}{l}=\| 1 / 4 \\
\text { Scherzen, ist zuweilen wol erlaubt // Dann es } \\
\text { macht ein all zu frener Scherz (Gil) } \\
\text { The scene has been slightly shortened by Clito's } \\
\text { replicas. }\end{array}$ \\
\hline $\begin{array}{l}\text { II/5 } \\
\text { Rapirò quelle crudel // Goderò lieto, e contento } \\
\text { (Pall) }\end{array}$ & $\begin{array}{l}\text { = II/5 } \\
\text { Ihren Rauber soll mich nennen // Da ihr Grimm } \\
\text { von mir besiegt (Sit) } \\
\text { Slightly shortened by Clito, speaking in his sleep in } \\
1729 \text { Prague version. }\end{array}$ \\
\hline $\begin{array}{l}\text { II/6 } \\
\text { Se andar sù per scala // Già poco più vivo (Cli) }\end{array}$ & $\begin{array}{l}=I I / 6 \text { omitted Clito's monologue and aria. Instead, } \\
\text { the start of scene II/7 from Prag } 1729 \text { - Aristeo's } \\
\text { monologue, without the introductory chorus. }\end{array}$ \\
\hline $\begin{array}{l}\text { II/7 } \\
\text { Frà Danze lubriche // Amor, e Venere (Coro) } \\
\text { Fulmini sù quel perfido (Aris, Ev, Pall, Sit, Dor, Gil) }\end{array}$ & $\begin{array}{l}\text { = II/7 } \\
\text { Ergötzt euch, Verlobte, durch frohes Bezeigen } \\
\text { (Coro) } \\
\text { Mit entflammten Donner Keilen (Aris, Ev, Pall, Sit, } \\
\text { quartetto) } \\
\text { It starts with a chorus, which in Prague } 1729 \text { is the } \\
\text { repetition of the chorus from the beginning of the } \\
\text { scene. The comparison of both versions looks like } \\
\text { this: } \\
\text { Prague } 1729 \\
\text { Vienna, Graz } 1741 \\
\text { II/6 Clito's solo + aria } \\
\text { Scene change } \\
\text { II/7 } \\
\text { Coro } \\
\text { Aristeo solo } \\
\text { Coro Da Capo } \\
\text { Other characters come to stage, recitative, the } \\
\text { scene ends with a quartet. } \\
\text { Scene change } \\
\text { II/6 }\end{array}$ \\
\hline
\end{tabular}




\begin{tabular}{|c|c|}
\hline Aristeo, Prague 1729 & Aristheus, Vienna - Graz 1741 \\
\hline & $\begin{array}{l}\text { Aristheus alone } \\
\text { II/7 } \\
\text { Chorus } \\
\text { Other characters come to stage, recitative, the } \\
\text { scene ends with a quartet that ends the act. }\end{array}$ \\
\hline $\mathrm{II} / 8$ & deleted \\
\hline $\begin{array}{l}\text { II/9 } \\
\text { Cospetton, cospettonaz // Lu nel sen fà del bravaz } \\
\text { (Maschera) } \\
\text { Polpetton, e sanguinazzo // Polli arrosti, e Trippe } \\
\text { à guazzo (Cli) }\end{array}$ & deleted \\
\hline $\begin{array}{l}\text { III/1 } \\
\text { Fra questi lacci, almen (Aris) }\end{array}$ & $=\mathrm{III} / 1$ \\
\hline $\mathrm{III} / 2$ & $=I I I / 2$ \\
\hline $\begin{array}{l}\text { III/3 } \\
\text { Non si può / Ciel che farò? (Dor) } \\
\text { Nè mai / A i nostri lai (Aris) } \\
\text { Al tuo sen mi unisca ò cara/caro // Stringi, abbrac- } \\
\text { cia (Dor, Aris, duetto) }\end{array}$ & $\begin{array}{l}=11 / / 3 \\
\text { Diese Brust liebt dich allein // Hier ist die Getreue } \\
\text { Hand (Aris, Dor, duetto) } \\
\text { The duet is a paraphrase. }\end{array}$ \\
\hline $\begin{array}{l}\text { III/4 } \\
\text { Voglio stragge, e voglio morte // Cadrà l'empio - E } \\
\text { la Germana (Ev) }\end{array}$ & $\begin{array}{l}=\mathrm{III} / 4 \\
\text { Mord und Tod, Schwert und Verderben // Er vergeb, } \\
\text { und auch bei ihm (Ev) }\end{array}$ \\
\hline \begin{tabular}{|l} 
III/5 \\
Vedi di chi son io? // Cedo per questo Ciglio (Gil)
\end{tabular} & $\begin{array}{l}=\text { III/5 } \\
\text { Mein Herz bleibt hier // Getreu zu sein (Gil) }\end{array}$ \\
\hline $\begin{array}{l}\text { III/6 } \\
\text { A chi turba la mia pace // Chi può farmi contumace } \\
(\mathrm{Pall})\end{array}$ & $\begin{array}{l}=\mathrm{III} / 6 \\
\text { Ja, ja, dir mich zu stürzen glaubet // Es hat, da er } \\
\text { zeigt mein Verbrechen (Pall) }\end{array}$ \\
\hline 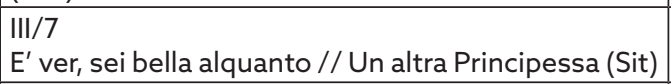 & $\begin{array}{l}=11 \mathrm{II} / 7 \text { without the aria (the aria lyric is summarized } \\
\text { in several verses of the recitative) }\end{array}$ \\
\hline $\begin{array}{l}\text { III/8 } \\
\text { Nò, non vuò, ch'altri m'annodi // Svelerò - le nere } \\
\text { frodi (Dor) }\end{array}$ & $\begin{array}{l}=111 / 8 \\
\text { Nein ich lieb kein anders Herz // Ich werd jene } \\
\text { falsche List (Dor) }\end{array}$ \\
\hline III/9 & deleted \\
\hline \begin{tabular}{|l} 
III/10 \\
Giurai di far vendetta // Se manco, una saetta (Gil)
\end{tabular} & $\begin{array}{l}=111 / 9 \\
\text { Was ich geschworen, ist die Rach // Und so ich die- } \\
\text { sen Schwur nicht halt (Aris) }\end{array}$ \\
\hline \begin{tabular}{|l|}
$\mathrm{III} / 11$ \\
Se cadi esangue // E di mia mano (Gil)
\end{tabular} & $\begin{array}{l}=I I I / 10 \text { without the aria (the last verse of the recita- } \\
\text { tive is a summary of the aria's content) }\end{array}$ \\
\hline $\begin{array}{l}\text { III/12 } \\
\text { Furie, che m'aggittate // Son reo, son traditore (Sit) }\end{array}$ & $\begin{array}{l}\text { continuation III/10 } \\
\text { Ihr Furien der Seelen // Kan meine That ein Schluß } \\
\text { der Sterne seyn? (Sit) }\end{array}$ \\
\hline \begin{tabular}{|l|} 
III/13 (Ultima) \\
\end{tabular} & $=\mathrm{III} / 11$ (Letzter Eintritt) \\
\hline $\begin{array}{l}\text { E' pur dolce quel contento // Fa men rigido il tor- } \\
\text { mento (Coro) }\end{array}$ & $\begin{array}{l}\text { continuation of the last number, } \\
\text { Uber Noct und Peinen siegen // Und der Lieb } \\
\text { Beständigkeit (Coro) }\end{array}$ \\
\hline
\end{tabular}




\section{Reasons and conditions for the 1741 German-language operas performances in Vienna and Graz}

After the death of Emperor Charles VI, there were favorable conditions in Vienna for productions of heroic, German-language drammi per musica. The staging of German operas required a sufficient number of singers with German as a mother tongue. At that time, the Kärntnertortheater employed many of them. ${ }^{52}$ The most well-known soprano was probably Rosalia Holzbauer, wife of Ignaz Holzbauer. Holzbauer, among others, performed in the 1741 Hypermnestra (the list of performers is recorded in a preserved score). Catharina Mayer, one of the most sought-after singers of the 1730s, and Maria Anna Eckardt, who died aged 25 in 1743, also sang in the Kärntnertortheater. At this time, Rosa Pasquali, born Schwarzmann and also known "la Bavarese", occasionally appeared as a guest in the Kärntnertortheater, though she also sang in Munich. There are also records of a female singer Drexler (perhaps Drechsler?), who has not yet been reliably identified. ${ }^{53}$ Among the native German female singers, there was a certain Cöllnerin, who has not been identified either. She undoubtedly worked in the Kärntnertortheater around 1730. Her presence at the Kärntnertortheater in the early 1740 s cannot be ruled out altogether either, because a singer of that name performed at the court of Count Thomas Vinciguerra of Collalto and San Salvatore in the 1760s. ${ }^{54}$ Bassist Anton Löhner (Lehner) also performed in the Kärntnertortheater. ${ }^{55}$ The same applied to Christoph Hager and a certain Hauer. His first name has not yet been identified, but he is known to have been active in Vienna for a long time. It is quite likely that he might be the "Herr Hauer" who, together with the unnamed court lutenist, visited Count Franz Anton von Sporck during his Vienna stay in $1727 .{ }^{56}$ Some of these singers apparently studied at the Sänger-Akademie, which had been operating at the Kärntnertortheater since 1728 and had the task to provide training for local local opera performers. ${ }^{57}$

But what were the reasons why the three original German-language operas were staged at the Kärntnertortheater in 1741? One possible cause, though probably a secondary one, could have been the the changing aesthetic preferences of the audience..$^{58}$ During the reign of Charles VI, parody operas in both Italian and German, called Musica

52 On male and female singers performing in Kärntnertortheater cf. PERUTKOVÁ 2016.

53 Cf. PERUTKOVÁ 2016.

54 Ibid.

55 Löhner was the only singer of the Kärntnertortheater who also served the nobility, at the estate of Count Johann Adam von Questenberg.

56 BOHADLO 2011, on Hauer on p. 47.

57 Cf. SOMMER-MATHIS 2015.

58 See, for example, Marko Motnik: "Der Wandel des Hofstils geht mit dem Wandel der teoretisch-ästhetischen Anschauungen und ihrer Umsetzung in die Praxis um etwa 1740 Hand in Hand." MOTNIK, Marko. Der Tanz im Umfeld des Wiener Hofes um 1740. In Im Dienste einer Staatsidee: Künste und Künstler am Wiener Hof um 1740 [= Wiener musikwissenschaftliche Beiträge; Bd. 24]. Ed. Elisabeth Th. Fritz. Wien: Böhlau Verlag, 2013, pp. $159-179$. 
bernesca, were played in the Kärntnertortheater in addition to Italian operas, ${ }^{59}$ together with German comedies that included musical numbers. The genre of German dramma per musica seems to be the next logical step in the development of the Theater's musical offerings ${ }^{60}$ It is not yet clear who the initiator of these efforts was. It is likely, that in this case one can see the realization of early Enlightenment tendencies supported considerably after 1740 by Franz Stephan von Lothringen. ${ }^{61}$ The important informations about German language refinement efforts and about claims of standard language (Hochdeutsch) was brought recently by Wynfrid Kriegleder. ${ }^{62}$ Due to his education and his experiences Johann Leopold van Ghelen might most likely have implemented the idea about a libretto written in refined German.

From a practical point of view, staging German operas in the spring of $1741 \mathrm{might}$ have resulted from the fact that during the mourning period after the death of Emperor Charles VI, Italian singers who had performed at the Kärntnertortheater in 1740 left Vienna to work elsewehere. ${ }^{63}$ However, this does not seem to be the main reason, since the remaining German artists were used to singing in Italian. In addition, Borosini and Selliers could have booked an Italian prima donna and possibly other Italian artists to perform Italian operas for significant events, such as the birth of the successor to the throne. Staging works in German must have been a result of some consideration.

Another interesting reason behind the 1741 productions of German-language works in the Kärntnertortheater was that practically simulataneously with the performance of Die glückliche Vorbedeutung, Joseph Carl Selliers received an important imperial decree from the Empress. In March 1741, Maria Theresa not only commissioned Selliers to produce court operas but also allowed him to rent the unoccupied Ballhaus at Michaelerplatz (later Burgtheater). After a renovation of the building, Selliers was planning to stage performances there not only for the nobility but also for the middle class, and these performances were to include German operas. ${ }^{64}$ Perhaps Selliers wanted to prove to Maria Theresa that he could easily produce German serious operas.

A more serious, perhaps crucial, reason for the production of German-language operas at the Kärntnertortheater, however, might have been the tense political situation

59 Librettos written, for example, by Heinrich Rademin, the most famous and most popular being Die römische Lucretia, cf. ERNST, Eva-Maria. Zwischen Lustigmacher und Spielmacher: Die komische Zentralfigur auf dem Wiener Volkstheater im 18. Jahrhundert. Berlin - Hamburg - Münster 2003; and STROHM 2014. Another author was Andreas Weidner, who wrote Bajazeth und Tamerlan.

60 Cf. STROHM 2014.

61 ZEDINGER, Renate. Franz Stephan von Lothringen (1708-1765): Monarch, Manager, Mäzen. Wien: Böhlau Verlag, 2008. I am very grateful to Otto Biba for his input to this problematic.

62 Cf. KRIEGLEDER, Wynfrid. Die deutschsprachige Literatur in Wien um 1740. In Im Dienste einer Staatsidee: Künste und Künstler am Wiener Hof um 1740 [= Wiener musikwissenschaftliche Beiträge; Bd. 24]. Ed. Elisabeth Th. Fritz. Wien: Böhlau Verlag, 2013, pp. 47-64 (hereinafter KRIEGLEDER 2013).

63 In the autumn of 1741, however, the Kärntnertortheater performed in Italian: Antigona (Libretto in A-Wn, sign. 444. 501-AM) and Didone abbandonata (Libretto in A-Wst, sign. A 102387).

64 SOMMER-MATTHIS, Andrea. Höfisches Theater zwischen 1735 und 1745. Ein Wendepunkt? In Im Dienste einer Staatsidee: Künste und Künstler am Wiener Hof um 1740 [= Wiener musikwissenschaftliche Beiträge; Bd. 24]. Ed. Elisabeth Th. Fritz. Wien: Böhlau Verlag, 2013, pp. 109-123, especially pp. 117-118. The first performance in the renovated Burgtheater took place in February 1742. 
of 1741 and the need to display official expressions of loyalty to the Habsburg dynasty in German. An important factor was that these performances were not produced by the court and exclusively for the court, but also for bourgeois audiences (both in Vienna and Graz). From the outset, the year 1741 was marked by the War of the Austrian Succession, in which the Habsburg monarchy faced the rejection of the Pragmatic Sanction. Proclaimed in 1713, the Sanction established the indivisibility of the Habsburg possessions and, in case of the extinction of the Habsburg male line, the succession of the female line. Emperor Charles VI devoted a lot of energy to its enforcement.

Since art was a powerful tool of Habsburg political propaganda, the creation of numerous musical-dramatic works was connected to the Pragmatic Sanction. This is the case of Costanza e fortezza (P. Pariati/J. J. Fux), which was performed in 1723 in Prague on the occasion of Charles VI's coronation as the Bohemian king became one of the largest operatic events in Central Europe in the first half of the 18th century. ${ }^{65}$ Rainer Kleinertz also speaks of the operas Teofane (S. B. Pallavicino/A. Lotti), performed in 1719 in Dresden, and Adelaide (A. Salvi/P. Torri), written in 1722 and staged in Munich; both operas were created for the wedding celebrations of Habsburg princesses. Finally, Kleinertz also sees the Pragmatic Sanction as related to Metastasio's first Viennese libretto written for Charles VI - Demetrio (set to the music by A. Caldara and staged for the first time to celebrate the Emperor's birthday in 1731) ${ }^{66}$ It was not by accident that this libretto served as the model for Die glückliche Vorbedeutung. In the Habsburg Empire, for example, the introduction of the La forza dell'amicizia in Graz in 1728, on the occasion of the birthday of Empress Elisabeth Christine, was also linked to the imposition of the Pragmatic Sanction. ${ }^{67}$ Evidence that Maria Theresa has continued the tradition of linking music and politics can also be seen in the introduction of Semiramide riconosciuta at her coronation in Prague in 1743. As suggested by Milada Jonášová, Maria Theresa seems to have liked this theme more than any other. The opera is about an admirable woman and ends with a general celebration of a sovereign who - without the knowledge of her subjects - has ruled the country disguised as a man for years. The final message

65 VÁCHA, Štěpán - VESELÁ, Irena - VLNAS, Vít - VOKÁČOVÁ, Petra. Karel VI. a Alžběta Kristýna. Česká korunovace 1723 [Charles VI and Elisabeth Christine. The bohemian coronation in 1723]. Praha - Litomyšl 2009. VESELÁ, Irena. Venga quel Dì felice! Dynastisch-politische Botschaften in musikalischen Huldigungswerken für Karl VI. und Elisabeth Christine (1723). In Die Repräsentation der Habsburg-Lothringischen Dynastie in Musik, visuellen Medien und Architektur / Representing the Habsburg-Lorraine Dynasty in Music, Visual Media and Architecture. 1618-1918. Ed. Werner Telesko. Wien-Köln-Weimar: Böhlau Verlag, 2017, pp. 135-158. Available online [11. 6. 2018] https://www.vr-elibrary.de/doi/pdf/10.7767/9783205207153.135.

66 KLEINERTZ, Rainer. Thronfolge als Problem: zur Bedeutung der Pragmatischen Sanktion von 1713 für das Dramma per musica. In Maria Theresas Kulturwelt. Geschichte, Religiosität, Literatur, Oper, Ballettkultur, Architektur, Malerei, Kunsttischlerei, Porzellan und Zuckerbäckerei im Zeitalter Maria Theresias [Beiträge des an der Arbeitsstelle für Österreichische Literatur und Kultur der Universität des Saarlandes vom 14 . bis zum 16. Juni 2007 abgehaltenen Kolloquiums]. Eds. Pierre Béhar, Marie-Thérèse Mourey and Herbert Schneider. [= Documenta Austriaca - Literatur und Kultur in den Ländern der ehemaligen Donaumonarchie 2). Hildesheim [u.a.]: Olms, 2011, pp. 77-90.

67 KARPF, Roswitha Vera. "Die ganze Welt ist eine Bühne". Musik and Repräsentation bei der Erbhuldigung von 1728. In Theater in Graz (= Historisches Jahrbuch der Stadt Graz, Bd. 15). Eds. Friedrich Bouvier and Helfried Valentinitsch, 1984, pp. 53-77. ZEDLER, Andrea - PERUTKOVÁ, Jana. "opera politica” - Grazer Opernaufführungen im Spannungsfeld der Pragmatischen Sanktion. In print. 
of the opera is also important: the rule of a woman can be successful and beneficial for everyone. ${ }^{68}$ The opera Barsene which was also performed during the coronation in Prague and which has recently been found in Rome has an identical plot. ${ }^{69}$ Here, the main theme has to do with the defeat of the Parthian king Fraarte and his troops and the celebration of the virtuous heroine Barsene. Josef Selliers was entrusted with staging both works for the events in Prague.

Let us return to 1741 now: after the death of Emperor Charles VI, the Pragmatic Sanction was viewed by many as void. Three sovereigns attacked Maria Theresa's inheritance rights - the Bavarian Elector Karl Albrecht, the Saxon Elector and the King of Poland Friedrich August II, and the Brandenburg Elector and King of Prussia Friedrich II. In December 1740 the troops of Friedrich II invaded Silesia. The war events headed towards victory of the Prussians at the Battle of Mollwitz, which took place on April 10, 1741. In this difficult situation, the celebrations of the birth of Joseph, the successor to the throne, including the staging of the Die glückliche Vorbedeutung, turned into a manifestation of the unity of the Empire.

The political situation is undoubtedly related to topics of all the 1741 German-language operas: Die glückliche Vorbedeutung is a celebration of the birth of the son - heir to the throne, the future hope of the dynasty, and the savior of the monarchy in the future. The figure of Feldherr Otin, who was added to the Metastasio's original Demetrio, is clearly a reflection of the succession wars. Otin evokes Odin/Wotan, the main Germanic god of war and death, but also a patron of poets and statesmen, and he only appears in the final scene, which has the character of a licenza. The scenery in this scene includes the temple of bliss of the ancient Germanic god Thor, in which Thor's priest declares "[...] auf viele mit-stimmende Instrumenten künstlich verfasseten Madrigal". There is a strong emphasis on German mythological deities, whom the work connects to the recently born Joseph - the future Emperor of the Holy Roman Empire. ${ }^{70}$ This connection becomes particularly clear in Othin's recitative in the final scene: "Auf dem Vogeso dort / zwey Stamme pflanzen wird, / die tausend Wölcker dieser Erden / durch Milde, und Gerechtigkeit / beschatten werden, / aus deren abermal begückter Einigung / ein so gewünschter Zweig / Empor wird steigen, / vor dem in Ihr Forcht sich die halbe Welt wird beugen."

Scene I/8 is also worth discussing. Rambertus first tells the main heroin Engeltrida, whose name was certainly not chosen by chance (Engel = angel): "Wie glücklich bin ich doch, / daß ich allhier bey deinen Füssen, / o Königin: / Nach also vielen Unglücks-Streichen / mich gleichwol noch / gewünschter Massen sehen, / und Engeltrida hier / auf denen ThronesHöhen / von diesem Reich verehren kan [sic!].” In addition, there is a strategic discussion of how to deal with war; at the end, Engeltrida says: "Das ganze Volk soll diesen Zwitracht

68 JONÁŠOVÁ, Milada. Semiramide riconosciuta - opera k pražské korunovaci Marie Terezie 1743 [Semiramide riconosciuta - opera on the Prague coronation of Maria Theresa in 1743]. In Barokni Praha - barokni Čechie 1620-1740. Proceedings of the Scientific Conference on the Baroque phenomenon in Bohemia. Prague, Convent of St. Agnes of Bohemia and Clam-Gallas Palace on September 24-27, 2001. Eds. Olga Fejtová, Václav Ledvinka, Jiří Pešek and Vít Vlnas. Praha: Scriptorium 2004, pp. 19-68.

69 Libretto in I-Rn, sign. 35. 6.B.15.6. This very interesting libretto will be discussed in a separate study.

70 I would like to thank Vlasta and Hubert Reitterer for a consultation on this topic. 
heben. / Entweder will ich frey regieren, / wo nicht, so trette ich die Tron / freywillig wieder ab, / die ich Gebettener nur angenommen hab. / So wird alsdann von meinem Herz / die Freyheit nichtes kränken, / und wenigst ich dem, wem ich will, / die Neigung darffen schencken." (This part of the recitative is actually a paraphrase of Cleonice's original aria.) Engeltrida's aria follows, and it has an almost pastoral character that is possibly connected to the fact that the text addresses lower social classes (Ihr beglükte Bauerinnen...). Scene III/13 has a slightly different plot than the original: while in Demetrius, Alcesto's and Cleonice's love affair is addressed, Glückliche Vorbedeutung focuses on Engeltrida's rule. In the German scene, Rambertus pays homage to Engeltrida: "Du bist Wohlfart für das Reich, / und zu dem Thron gebohren." The claim of the main heroine to the throne is therefore sufficiently emphasized here.

After Die glückliche Vorbedeutung was premiered, the efforts to celebrate Maria Theresa intensified, mostly in connection to the worsening international political situation. This intensification drew on the panegyric techniques in the artworks associated with Emperor Charles VI. ${ }^{71}$ Perhaps that is why Hypermnestra, in which the female hero, princess Hypermnestra, rescues the rule of her dynasty and suppresses a rebellion, was chosen as the next German-language opera. Finally, in Aristheus, the main theme is a celebration of the noble Doriclis and Aristheus, who get married at the end of the opera. The opera was therefore yet another celebration of Maria Theresa, and this time also her husband, Duke Franz Stephan von Lothringen. Praise was heaped upon the couple's beauty and virtues in the libretto (it is an interesting fact that the Prague performance of Aristeo in 1729 was dedicated to the Duke as well). The couple has to ascend the throne despite difficulties, and one of the most prominent motifs of the opera is the couple's victory over robbers. The theme of the usurpation of the throne and the betrayal by a supposed friend (Sitalces) once again strongly hints at the political situation in 1741. At the same time, it cannot be verified at the present in what order Hypermnestra and Aristheus were produced after Die glückliche Vorbedeutung, because Wienerisches Diarium does not inform about their performances.

\section{Epilogue: Hypsipile}

Despite the fact that in 1741 at least three drammi per musica were staged in German at the Kärntnertortheater, the present state of research does not indicate any major growth of serious operas with original German texts followed in the 1740s.

Yet, in 2017, the author of this paper found one more original German-language libretto from the Kärntnertortheater of that period.

71 In the 1740s, Maria Theresa was still celebrated in non-musical works; in 1746, Franz Christoph Scheyb wrote the epos Theresiade. Ein Ehrengedicht, which described the Austrian succession wars in twelve volumes, but mainly sang praises to Maria Theresa. Cf. KRIEGLEDER 2013, pp. 47-64. 
Its title page reads:

HYPSIPILE | In einer Teutschen | OPERA | Auf dem Königl. privilegirten | TEATRO | In Wien | Vorgestellet. | J. L. v. G. | Die Büchlein darüber, seynd in dem | Comödien=Haus zu bekommen. ${ }^{72}$

As with Aristheus, little information is available, and there is no mention of the production year. Thanks to the inheritance inventory of Johann Matthias von Thurn and Valsassina, a canon in Olomouc and the provost of the collegiate chapter in the St. Peter and Paul Cathedral in Brno, who owned the score of this opera, at least the ante quem date - the year 1747 - is known. ${ }^{73}$

The title page is similar to that in Aristheus, including the layout of capital letters. The vignettes are also identical.

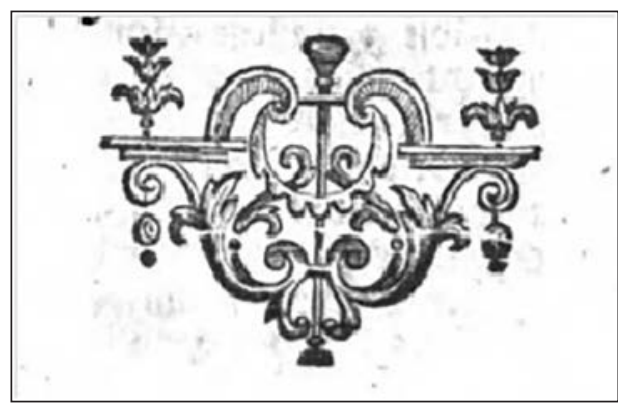

Fig. 4 Vignette, title page of Hypsipile, Aristheus or Didone abbandonata (all 1741)

The same vignette is also found, for example, on the title page of the opera Didone abbandonata, which was staged in the Kärntnertortheater in the autumn of 1741. Therefore, it cannot be ruled out that Hypsipile was also staged this year, for example in the autumn of the 1741-1742 season. However, this assumption has not yet be corroborated by other sources.

As was the case with Aristheus, the composer of Hypsipile is not mentioned in the libretto and the composition is not mentioned in other sources. The author of the libretto is once again Johann Leopold van Ghelen, whose initials are listed on the title page, and it was written in the same way as his previous German-language operas. The model for this libretto was Issipile by Pietro Metastasio, which was first set to music by Francesco

72 A-Wn, sign.26052-A; in the preserved copy, which for the time being seems unique, pages 43-46 in the libretto are missing.

73 In the heritage inventory, the work is referred to as "Teütsche opera von der Hyssipille". I am obliged for this information to Jana Spáčilová. Regarding the inventory cf. SEHNAL, Jiří. Nové poznatky k dějinám hudby na Moravě v 17. a 18. století [New findings about the history of music in Moravia in $17^{\text {th }}$ and $18^{\text {th }}$ centuries]. Časopis moravského musea 60, 1975, pp. 159-180. The opera Hypsipile had 146 pages, it was estimated at $7 \mathrm{fl}$. and sold for $9 \mathrm{fl}$. 
Bartolomeo Conti in 1732. Recitatives are rarely shortened, some arias are omitted, and some are paraphrased. ${ }^{74}$ The main character is the female heroine, the queen on the island of Lemnos, the daughter of the King Thoas; in this opera, war is also an aspect of the plot, and politics plays an important role in it; the opera must have also been an artistic response to the wars of the Austrian Succession and a celebration of Maria Theresa.

The three previously overlooked librettos of German-language drammi per musica Die glückliche Vorbedeutung, Aristheus and Hypsipile - increase our understanding of the operatic life at the Kärntnertortheater at the beginning of Maria Theresa's reign. These operas reflected political events caused by the failure of the Pragmatic Sanction and the invasions of the Habsburg monarchy by foreign troops. It also seems, that they could have been related with early Enlightenment ideas, which expanded in that period mainly thanks to Franz Stephan von Lothringen. It is possible that the operas were staged repeatedly, perhaps even in later years, but no sources corroborate such suppositions. Moreover, further findings of other German librettos from that period cannot be ruled out. The share of German-language performances of serious operas in the Kärntnertortheater in 1740 will by all means have to be subjected to further research.

\section{Bibliography}

\section{Sources}

\section{Libretti:}

Amoris in iudicio victoria oder Die obsiegende Liebe (Anon.), CZ-Pu, 52 C 20, adl. 29.

Antigona (Anon.), A-Wn, sign. 444.501-A.M.

Aristeo (Anon.), Cz-Pu, sign. 65 D 12.

Aristheus (Giovanni Cesare Corradi/Antonio Polarollo), I-Mb, RACC.DRAM.0763.

Aristheus (Anon.), A-Wn, sign. 26054-A. A-Gl, sign. 156904 I. US-Dmu, sign. Jantz B 12mo \# 3406 č. 5 [2972] c.1.

Barsene (Anon.), I-Rn, sign. 35. 6.B.15.6.

Debbora (Francesca Manzoni/Ignazio Maria Conti), A-Wn, sign. 25213-B.

Didone abbandonata (Anon.), A-Wst, sign. A 102387.

Die glückliche Vorbedeutung (Johann Leopold van Ghelen/Ignazio Maria Conti), UA-LVs, sign. No. CT 66524, old call number 38.874. B.

Die Liebe hat kein Gesatz (Giovanni Domenico Bonlini/ Antonio Caldara, translation: Martin Anton Prunauer), A-Baden, A 453.

Ezechia (Antonio Maria Lucchini/Ignazio Maria Conti), A-Wn, sign. 25218-B.

Hypsipile (Johann Leopold van Ghelen/ ?), A-Wn, sign. 26052-A.

Il figliuol prodigo (Giovanni Claudio Pasquini/Ignazio Maria Conti), A-Wn, sign. 25209-B.

Il giusto afflitto nella persona di Giobbe (Giovanni Claudio Pasquini /Ignazio Maria Conti), A-Wn, sign. 1810-B.

St. Paul zu Athen (Johann Leopold van Ghelen/Ignazio Maria Conti), A-Wn, sign. 4159-B.

74 A detailed table with a comparison of both librettos will be published in another study. 
Scores:

Hypermnestra (Johann Leopold van Ghelen/ Ignaz Holzbauer), D-MEIr, sign. Ed 130d.

L'amor prigioniero (Pietro Metastasio/Georg Reutter Jr.), A-Wn, sign. Mus.Hs. 17.726.

Others:

Wiennerische Beleuchtungen, A-ALT, sign. 47. Nn. 194.

SOkA Olomouc, Sg. Eg3, carton 1458, inventorial number 3328 (Applikation of Johann Ignaz Bayer).

RISM Online Catalogue of Musical Sources. URL: 〈www.rism.info〉.

\section{Literature}

BENNETT, Lawrence. Ignaz Holzbauer and the Origins of German Opera in Vienna. EighteenthCentury Music 3, 2006, pp. 63-90.

BOHADLO, Stanislav. Questenberg a Sporck - oddělené a nezávislé barokní hudební subkultury na Moravě a v Čechách? [Questenberg and Sporck - Separate and Independent Baroque Music Subcultures in Moravia and Bohemia?]. Musicologica Brunensia 46, 2011, iss. 1-2, pp. 15-34.

BRISTIGER, Michał - STROHM, Reinhard. „Libertà, marito e trono fur miei beni..." Die wiederentdeckte Andromaca von Antonio Bioni (Breslau 1730). In Opera Subjects and European Relationships [= Italian Opera in Central Europe, 1618-1780, Bd. 3]. Eds. Norbert Dubowy, Corinna Herr and Alina Żórawska-Witkowska. Berlin: BWV, 2007, pp. 73-109.

ČERNÁ, Zuzana. Antonio Bioni and his compositions preserved in Kroměříž archive. Musicologica Brunensia 52, 2017, iss. 2, s. 217-242. DOI: 10.5817/MB2017-2-18.

DIETRICH, Margaret. Theater am Hofe - Zwischen Tradition und Wandel. In Maria Theresia und ihre Zeit. Eine Darstellung der Epoche von 1740-1780 aus Anlass der 200. Wiederkehr des Todestages der Kaiserin, 2. Aufl. Ed. Walter Koschatzky. Salzburg: Residenz Verlag, 1980, pp. 393-403.

ERNST, Eva-Maria. Zwischen Lustigmacher und Spielmacher: Die komische Zentralfigur auf dem Wiener Volkstheater im 18. Jahrhundert. Berlin - Hamburg - Münster 2003.

FASTL, Christian - HILSCHER, Elisabeth Th. Phuniak (Phuniack, Funiak), Anton. In Oesterreichisches Musiklexikon online, cit. 11. 6. 2018, https://www.musiklexikon.ac.at/ml/musik_P/ Phuniak_Anton.xml.

HADAMOWSKY, Franz. Wien - Theatergeschichte. Von den Anfängen bis zum Ende des Ersten Weltkrieges [= Geschichte der Stadt Wien III]. Wien 1994, p. 195.

HOLZBAUER, Ignaz Jakob. Kurzer Lebensbegriff des Herrn Ignaz Holzbauer, kurpfälzischen Kapellmeisters. In Günther von Schwarzburg. Ed. Hermann Kretzschmar. Leipzig 1902.

HOLZBAUER, Ignaz. Hypermnestra. Ed. L. Bennett. Denkmäler der Tonkunst in Österreich, Bd. 157. Graz: ADEVA Musik, Akademische Druck- u. Verlagsanstalt, 2014.

JONÁŠOVÁ, Milada. Semiramide riconosciuta - opera k pražské korunovaci Marie Terezie 1743 [Semiramide riconosciuta - The Opera for the Prague Coronation of Maria Theresia in 1743]. In Barokni Praha - barokni Čechie 1620-1740. Proceedings of the Scientific Conference on the Baroque phenomenon in Bohemia. Prague, Convent of St. Agnes of Bohemia and Clam-Gallas Palace on September 24-27, 2001. Eds. Olga Fejtová, Václav Ledvinka, Jiř́i Pešek and Vít Vlnas. Praha: Scriptorium 2004, pp. 19-68.

KAPSA, Václav. Die Musik in der St. Nikolauskirche auf der Prager Kleinseite in der ersten Hälfte des 18. Jahrhunderts. Musicologica Brunensia 49, 2014, iss. 1, pp. 189-209, DOI: 10.5817/ MB2014-1-12. 
KARPF, Roswitha Vera. "Die ganze Welt ist eine Bühne”. Musik und Repräsentation bei der Erbhuldigung von 1728. In Theater in Graz (= Historisches Jahrbuch der Stadt Graz, Bd. 15). Eds. Friedrich Bouvier and Helfried Valentinitsch, 1984, pp. 53-77.

KLEINERTZ, Rainer. Thronfolge als Problem: zur Bedeutung der pragmatischen Sanktion von 1713 für das Dramma per musica. In Maria Theresias Kulturwelt. Geschichte, Religiosität, Literatur, Oper, Ballettkultur, Architektur, Malerei, Kunsttischlerei, Porzellan und Zuckerbäckerei im Zeitalter Maria Theresias [Beiträge des an der Arbeitsstelle für Österreichische Literatur und Kultur der Universität des Saarlandes vom 14. bis zum 16. Juni 2007 abgehaltenen Kolloquiums]. Eds. Pierre Béhar, Marie-Thérèse Mourey and Herbert Schneider. [= Documenta Austriaca - Literatur und Kultur in den Ländern der ehemaligen Donaumonarchie; 2]. Hildesheim [u.a.]: Olms, 2011, pp. 77-90.

KRIEGLEDER, Wynfrid. Die deutschsprachige Literatur in Wien um 1740. In Im Dienste einer Staatsidee: Künste und Künstler am Wiener Hof um 1740 [= Wiener musikwissenschaftliche Beiträge; Bd. 24]. Ed. Elisabeth Th. Fritz. Wien: Böhlau Verlag, 2013, pp. 47-64.

KUBISKA-SCHARL, Irena - PÖLZL, Michael. Die Karrieren des Wiener Hofpersonals 1711-1765. Eine Darstellung anhand der Hofkalender und Hofparteienprotokolle. Innsbruck - Wien - Bozen: StudienVerlag, 2013.

MICHELS, Claudia. Opernrepertoire in Wien um 1740: Annäherungen an eine Schnittstelle. In Im Dienste einer Staatsidee: Künste und Künstler am Wiener Hof um 1740 [= Wiener musikwissenschaftliche Beiträge; Bd. 24]. Ed. Elisabeth Th. Fritz. Wien: Böhlau Verlag, 2013, pp. 125-158.

MOTNIK, Marko. Der Tanz im Umfeld des Wiener Hofes um 1740. In Im Dienste einer Staatsidee: Künste und Künstler am Wiener Hof um 1740 [= Wiener musikwissenschaftliche Beiträge; Bd. 24]. Ed. Elisabeth Th. Fritz. Wien: Böhlau Verlag, 2013, pp. 159-179.

PAVLICA, Lukáš. Completorium a Cantata Johanna Ignaze Beyera - edice a analýza. [Completorium and Cantata by Johann Ignaz Beyer - Edition and Analysis]. Diploma thesis, supervisor: Jana Perutková, Brno: FF MU, 2018.

PEGAH, Rashid-Sascha. Antonio Bioni und seine "Cantate Musicali” für Markgräfin Friderique Louise von Brandenburg-Ansbach. Jahrbuch für fränkische Landesforschung 72, 2012, pp. 185-198. PERUTKOVÁ, Jana. Der glorreiche Nahmen Adami. Johann Adam Graf von Questenberg (1678-1752) als Förderer der italienischen Oper in Mähren (= Specula Spectacula 4). Wien: Hollitzer Verlag, 2015.

PERUTKOVÁ, Jana. Giulio Cesare in Egitto am Wiener Kärntnertortheater im Jahre 1731. Ein Beitrag zur Rezeption der Werke von G. F. Händel in der Habsburgermonarchie in der 1. Hälfte des 18. Jahrhunderts. Hudebni věda 49, 2012, iss. 1-2, pp. 95-122. Available online [11. 6. 2018] https:// kramerius.lib.cas.cz/search/nimg/IMG_FULL/uuid:eb56bc08-d1d8-46f7-be9f3e23991b84d8\#page $=1$.

PERUTKOVÁ, Jana. Vienna Kärntnertortheater Singers in the Letters from Georg Adam Hoffmann to Count Johann Adam von Questenberg. Italian Opera Singers in Moravian Sources c. 1720-1740 (Part II). In Musicians' Mobilities and Music Migrations in Early Modern Europe. Biographical Patterns and Cultural Exchanges. Eds. Gesa zur Nieden, Gesa and Berthold Over. Bielefeld: Transcript Verlag, 2016, pp. 275-292. Available online [11. 6. 2018] https:// www. transcript-verlag.de/media/pdf/24/94/a7/oa97838394350455b19e250cbe52.pdf.

PERUTKOVÁ, Jana. Von der mährischen Aristokratie in der ersten Hälfte des 18. Jahrhunderts veranstaltete musikdramatische Aufführungen als Spiegel musikalischer Feste am Wiener Kaiserhof. In Die Repräsentation der Habsburg-Lothringischen Dynastie in Musik, visuellen Medien und Architektur/ Representing the Habsburg-Lorraine Dynasty in Music, Visual Media and Architecture. 1618-1918. Ed. Werner Telesko. Wien-Köln-Weimar: Böhlau Verlag, 2017, pp. 284-300. Available online [11. 6. 2018] https:/ / www.vr-elibrary.de/doi/pdf/10.7767/9783205207153.284. 
RUDIN, Bärbel. Wien - Berlin - Riga: Commedia dell'arte auf Wanderschaft: Andreas Weidner, Johann Peter Hilverding und "Die entsetzlichen Zufälle in Glück- und Unglückswechsel”. In Im Spiegel der Theatergeschichte: deutschsprachiges Theater im Wechsel von Raum und Zeit. Eds. Paul S. Ulrich, Gunilla Dahlberg and Horst Fassel. Münster: LIT Verlag Münster, 2015, pp. 21-59.

SARTORI, Claudio. I libretti italiani a stampa dalle origini al 1800. Catalogo analitico con 16 indici. Cuneo: Bertola \& Locatelli, 1990-1994.

SEHNAL, Jiří. Das Musikinventar des Olmützer Bischofs Leopold Egk aus dem Jahre 1760 als Quelle vorklassischer Instrumentalmusik. Archiv für Musikwissenschaft 29, 1972, iss. 4, pp. 285-317.

SEHNAL, Jiří. Ignaz Jakob Holzbauer. In Theater in Böhmen, Mähren und Schlesien. Von den Anfängen bis zum Ausgang des 18. Jahrhunderts. Ein Lexikon. Neu bearbeitete, deutschsprachige Ausgabe. Eds. Alena Jakubcová and Matthias J. Pernerstorfer [= Theatergeschichte Österreichs, Bd. X: Donaumonarchie, Heft 6], Wien - Praha 2013 pp. 288-289.

SEHNAL, Jiří. Nové poznatky k dějinám hudby na Moravě v 17. a 18. století [New Findings about the History of Music in Moravia in $17^{\text {th }}$ and $18^{\text {th }}$ Centuries]. Časopis moravského musea 60,1975 , pp. 159-180.

SOMMER-MATHIS, Andrea. Die Anfänge des Wiener Kärntnertortheaters zwischen deutschsprachiger Stegreifkomödie und italienischer Oper. Divadelni revue 26, 2015, iss. 2, pp. 139-152.

SOMMER-MATTHIS, Andrea. Höfisches Theater zwischen 1735 und 1745. Ein Wendepunkt? In Im Dienste einer Staatsidee: Künste und Künstler am Wiener Hof um 1740 [= Wiener musikwissenschaftliche Beiträge; Bd. 24]. Ed. Elisabeth Th. Fritz. Wien: Böhlau Verlag, 2013, pp. 109-123.

SPÁČILOVÁ, Jana. Počátky opery ve Slezsku - současný stav pramenů [The Origins of Opera in Silesia - Current State of Sources]. Musicologica Brunensia 51, 2016, iss. 2, pp. 157-170. DOI: 10.5817/MB2016-2-12.

STROHM, Reinhard. Ignaz Holzbauers Hypermnestra (1741). Zur Geschichte und Interpretation des Librettos. Studien zur Musikwissenschaft 58, 2014, pp. 133-170.

STROHM, Reinhard. Demetrio by Pietro Metastasio and Johann Adolf Hasse: a dramma per musica for Vienna and Venice. In STROHM, Reinhard - MENCHELLI-BUTTINI, Francesca (eds.). Pietro Metastasio - Johann Adolf Hasse, Demetrio. Facsimile edition of the score; edition of the libretto by Francesca Menchelli-Buttini; introductory essays by Reinhard Strohm and Francesca Menchelli-Buttini [= Drammaturgia musicale veneta, 17]. Milan: Ricordi, 2014, pp. vii-lviii.

VÁCHA, Štěpán - VESELÁ, Irena - VLNAS, Vít - VOKÁČOVÁ, Petra. Karel VI. a Alžběta Kristýna. Česká korunovace 1723 [Charles VI and Elisabeth Christine. The Bohemian Coronation in 1723]. Praha - Litomyšl 2009.

VESELÁ, Irena. Venga quel Dì felice! Dynastisch-politische Botschaften in musikalischen Huldigungswerken für Karl VI. und Elisabeth Christine (1723). In Die Repräsentation der HabsburgLothringischen Dynastie in Musik, visuellen Medien und Architektur/ Representing the Habsburg-Lorraine Dynasty in Music, Visual Media and Architecture. 1618-1918. Ed. Werner Telesko. Wien Köln - Weimar: Böhlau Verlag, 2017, pp. 135-158. Available online [11. 6. 2018] https://www. vr-elibrary.de/doi/pdf/10.7767/9783205207153.135.

WALTER, Friedrich. Geschichte des Theaters und der Musik am Kurpfalzischen Hofe. Hildesheim: Olms, 1968.

ZEDINGER, Renate. Franz Stephan von Lothringen (1708-1765): Monarch, Manager, Mäzen. Wien: Böhlau Verlag, 2008.

ZEDLER, Andrea - PERUTKOVÁ, Jana. “opera politica” - Grazer Opernaufführungen im Spannungsfeld der Pragmatischen Sanktion. In print. 
